\title{
Gas emissions, tars, and secondary minerals at the Ruth Mullins and Tiptop coal mine fires
}

\author{
Jennifer M.K. O'Keefe ${ }^{a}$, Erika R. Neace ${ }^{\mathrm{a}, 1}$, Max L. Hammond III $^{\mathrm{a}, 2}$, James C. Hower ${ }^{\mathrm{b}, *}$, \\ Mark A. Engle ${ }^{\mathrm{c}}$, Joseph East ${ }^{\mathrm{c}}$, Nicholas J. Geboy ${ }^{\mathrm{c}}$, Ricardo A. Olea ${ }^{\mathrm{c}}$, Kevin R. Henke ${ }^{\mathrm{b}}$, \\ Gregory C. Copley ${ }^{\mathrm{b}}$, Edward Lemley ${ }^{\mathrm{a}, 3}$, Rachel S. Hatch Nally ${ }^{\mathrm{b}, 4}$, Antonia E. Hansen ${ }^{\mathrm{b}, 2}$, \\ Allison R. Richardson ${ }^{\mathrm{b}}$, Anne B. Satterwhite ${ }^{\mathrm{b}}$, Glenn B. Stracher ${ }^{\mathrm{d}}$, Larry F. Radke ${ }^{\mathrm{e}}$, \\ Charles Smeltzer ${ }^{\mathrm{f}, 5}$, Christopher Romanek ${ }^{\mathrm{g}}$, Donald R. Blake ${ }^{\mathrm{h}}$, Paul A. Schroeder ${ }^{\mathrm{i}}$, \\ Stephen D. Emsbo-Mattingly ${ }^{j}$, Scott A. Stout ${ }^{j}$
}

${ }^{a}$ Department of Earth and Space Sciences, Morehead State University, Morehead, Kentucky 40351, USA

b Center for Applied Energy Research, University of Kentucky, Lexington, Kentucky 40511, USA

${ }^{\mathrm{c}}$ US Geological Survey, Eastern Energy Resources Science Center, Reston, Virginia 20192, USA

d Department of Geology, East Georgia College, Swainsboro, Georgia 30401, USA

e Airborne Research Consultants, Saunderstown, Rhode Island 02875, USA

${ }^{\mathrm{f}}$ Georgia Institute of Technology, Atlanta, Georgia 30332, USA

${ }^{g}$ Department of Earth and Environmental Sciences, Furman University, Greenville, South Carolina 29613, USA

h Department of Chemistry, University of California at Irvine, Irvine, California 92697, USA

${ }^{i}$ Department of Geology, University of Georgia, Athens, Georgia 30602-2501, USA

${ }^{\mathbf{j}}$ New Fields Environmental Forensics Practice, 100 Ledgewood Place, Suite 302, Rockland, Massachusetts 02370, USA

\section{A R T I C L E I N F O}

\section{Keywords:}

Coal fire

Greenhouse gases

Condensate minerals

Tar

\begin{abstract}
A B S T R A C T
Both the Tiptop and Ruth Mullins coal fires, Kentucky, were reinvestigated in 2009 and 2010. The Tiptop fire was not as active in 2009 and may have been on the path to burning out at the time of the 2009 visit. The Ruth Mullins coal mine fire, Perry County, Kentucky, has been the subject of several field investigations, including November 2009-February 2010 investigations in which we measured gas emissions, collected minerals and tars, and characterized the nature of the fire. Vents exhibiting the greatest gas flux $\left(>100,000 \mathrm{mg} / \mathrm{s} / \mathrm{m}^{2}\right)$ are those with the largest amount of condensate minerals and tars. Vents with moderate gas flux (10,000-100,000 mg/s/ $\mathrm{m}^{2}$ ) are less likely to contain condensate minerals, but are collocated with tars, and vents with the lowest flux $\left(<10,000 \mathrm{mg} / \mathrm{s} / \mathrm{m}^{2}\right)$ generally lack both minerals and tars. Aliphatic hydrocarbons present in the gases include C1-C9 compounds, and aromatics include BTEX compounds. Diffuse- $\mathrm{CO}_{2}$ emissions are concentrated along the fracture zones overlying abandoned mine works. The area of peak diffuse flux corresponds to the trend of the collapsed portal that forms vent 5 . The greatest vent emissions were also recorded at vent 5 . The snow-melt zone mapped in January 2010 overlies the areas of peak diffuse- $\mathrm{CO}_{2}$ emissions measured in November; together they delineate the zone of active combustion. Comparison of greenhouse gas emissions from the two sources shows that vent emissions exceed diffuse emissions. The highly fractured, quartz-cemented roof rock funnels the majority of emissions toward the vents. Significant decreases are seen in estimates of yearly greenhouse emissions based on data gathered from November 2009 to February 2010, with estimates from November significantly exceeding any previously published estimates. For example, September 2009 estimates from vent 3 alone indicated that $19 \pm 7.5 \mathrm{~T} \mathrm{CO} / \mathrm{yr}$ were emitted while the November 2009 estimates were $1800 \pm 690 \mathrm{~T} / \mathrm{yr}$.
\end{abstract}

\footnotetext{
* Corresponding author.

E-mail address: james.hower@uky.edu (J.C. Hower).

${ }^{1}$ Now at: Howard Hughes Medical Institute, Chevy Chase, MD 20815.

${ }^{2}$ Now at: Kentucky Geological Survey, Lexington, KY 40506.

${ }^{3}$ Now at: 10-2 Communications and Services, London, KY 40744.

${ }^{4}$ Now at: Brown-Forman, Louisville, KY 40210.

${ }^{5}$ Now at: Xerxsed, Roswell, GA 30076.
} 
Barometric pressure was lower in November than September. This implies that there are many factors influencing the seasonal variations in fire emissions and that more frequent monitoring will be necessary to derive accurate estimates of coal fires' contribution to the carbon budget.

\section{Introduction}

Coal fires destroy valuable energy resources and damage ecosystems; they have the potential to damage infrastructure and adversely impact human health. They are a poorly understood source of both greenhouse gases and particulate matter. Coal fires and their environmental implications have gained worldwide attention (Stracher et al., 2010) and steps are being taken to further quantify the extent and potential impact of many of these fires. Ongoing work in India and China (Jiang et al., 2011; Mishra et al., 2011; Prakash et al., 2011; Wu and Liu, 2011; Prakash et al., 2009; Prakash and Berthelote, 2007; Singh et al., 2007; Zhang and Kuenzer, 2007; Chatterjee, 2006; Prakash and Vekerdy, 2004; Gupta and Prakash, 1998) and work in Wyoming (Engle et al., 2011, 2012a) has shown that remote sensing is an extremely valuable tool in monitoring large-scale fires underlying relatively flat strata. Unlike many fires worldwide, the known fires burning in eastern Kentucky do not occur below thin veneers of poorly indurated sediment; they occur in abandoned underground coal mines beneath thick, indurated rocks within a mountainous terrain. The lone exception is the Fishtrap Lake fire, which is visible using MODIS infrared satellite imagery (M. Ruminski, personal communication to Hower et al., 2011). In these settings, ground-based measurements can take the place of remote-sensing in terms of monitoring the extent and migration of the fire. While time consuming, these techniques have the added bonus of providing valuable emissions data necessary for assessing the potential human health and infrastructure impacts. Human health impacts are of especial concern, as many of the fires in Kentucky and worldwide occur near populous areas; indeed, the April 2011 Appalachian Community \& Ecosystems Health Summit (http://www. appsciencesummit.eku.edu/) identified coal fires as a point source of concern within the spectrum of cradle-to-grave coal resource contaminants. Before this concern can even be addressed, however, much more information is needed on coal fire emissions and dynamics.

Studies of coal fires in Kentucky have concentrated on the six mine fires that are most easily accessible: Laura Campbell (Stracher et al., 2008), Ruth Mullins (Hower et al., 2011; Silva et al., 2011a, 2011b; O'Keefe et al., 2010), Truman Shepherd (O'Keefe et al., 2010; Hower et al., 2013; Dindarloo et al., 2015), Old Smokey (O'Keefe et al., 2011), Tiptop (Hower et al., 2009), and Lotts Creek (Hower et al., 2012; Garrison et al., 2017). ${ }^{6}$ The Ruth Mullins coal mine fire (Fig. 1) is the most studied coal fire in eastern Kentucky. The fire was first visited by Hower, Stracher, and others in March 2007. Following remediation in the spring of 2007, it was thought to be extinguished until smoke was noted on the opposite side of the ridge in September 2007. Hower, O'Keefe, and others visited the site shortly after reports of smoke were received and they were able to see flames and glowing embers on the floor of one abandoned mine shaft and smoke exiting several others. At that time, all abandoned mine portals on the exposed ridge face were intact and no slumping had occurred. Since 2007, the Ruth Mullins site has changed significantly. Large blocks have slumped away from the cliff face and all mine portals have collapsed. Trees have fallen as the roots were burned from the bottom up. In the space of the 10 months of this study, more slumping was apparent, and since the completion of this study, progressive failure of the highwall has continued. This fire has not been extinguished and poses eventual risk to Kentucky Highway (KY) 80, a major four-lane divided regional highway, and possibly the reclaimed mine on the far side of $\mathrm{KY} 80$. A service station is located near the fire, and while not in any danger from the fire, per se, continued exposure to emissions could impact the employees' health.

The Tiptop coal mine fire (Fig. 1) has been examined on multiple occasions since 2008. Fire flare-ups ignited forest fires on the overlying slopes in fall 2008 and summer 2009. Following both forest fires, remediation of the active burn zone was attempted. This consisted of pushing loose dirt over the exposed mine shafts and auger holes. These efforts were largely unsuccessful in extinguishing the fire, although the later efforts resulted in significantly decreased emissions. This fire is located in a single isolated ridge surrounded by active underground and surface mining operations, directly across a valley from a coal preparation plant. The mining operations are in no danger from the fire, although the health of mine employees and preparation plant workers could potentially be impacted by the emissions.

\subsection{Prior work}

The Ruth Mullins and Tiptop coal mine fires have been under investigation since the spring of 2007 (Stracher et al., 2008; O'Keefe et al., 2010) and the spring of 2008 (Hower et al., 2009), respectively. These investigations made first-order quantifications of $\mathrm{CO}_{2}, \mathrm{CO}$, and $\mathrm{Hg}$ vent gas concentrations using Dräger tubes and an Arizona Instruments Jerome 431-X Mercury Vapor Analyzer. The S-type pitot tube in conjunction with a Flow Kinetics FKT 1 1DP1A-SV flow meter, as was used for the Wyoming studies (Engle et al., 2011, 2012a), was first employed at the Ruth Mullins fire in the spring of 2009, allowing vent emission estimates to be calculated (O'Keefe et al., 2010).

Results from these basic surveys indicate that vent temperatures in both cases range between ambient and extreme $\left(291\right.$ - > 300 $\left.{ }^{\circ} \mathrm{C}\right)$ temperatures, with greatest concentrations of greenhouse gases recorded from the hottest vents. In all cases, Dräger tube-indicated CO concentrations exceeded OSHA 8-h limits (>50 ppm). In many cases, Dräger tube-indicated $\mathrm{CO}_{2}$ concentrations also exceeded OSHA 8-h limits of $0.5 \mathrm{vol} \%$, ranging from $0.25-6.0 \mathrm{vol} \%$. The Jerome instrument provided very low elemental $\mathrm{Hg}$ vapor concentrations at the Ruth Mullins fire, between 0.009 and $0.560 \mu \mathrm{g} / \mathrm{m}^{3}$, although still above typical background concentrations of about $1.5 \mathrm{ng} / \mathrm{m}^{3}$. The Jerome instrument provided significantly higher concentrations at the Tiptop fire, ranging from $<9-580 \mu \mathrm{g} / \mathrm{m}^{3}$. High benzene and other volatile organic compounds (VOCs) were measured at both sites. Initial vent velocity measurements at Ruth Mullins ranged from $0.25-0.95 \mathrm{~m} / \mathrm{s}$. Prior to the current work, vent velocity measurements had not been made at the Tiptop mine fire.

These initial analyses allowed us to estimate that Ruth Mullins is emitting roughly $734 \mathrm{~T}$ of $\mathrm{CO}_{2}, 21 \mathrm{~T}$ of $\mathrm{CO}$, and $0.84 \mathrm{~T}$ of $\mathrm{Hg}$ per year. We expect that overall greenhouse gas emission estimates from the initial survey of Tiptop will be similar, given similar conditions, although $\mathrm{Hg}$ emissions are likely higher. When compared to coal-fired power plants and larger fires in the United States (Engle et al., 2011, 2012a; Ide and Orr, 2011), emission estimates from both Ruth Mullins and Tiptop are small. However, when multiplied by the number of fires of this size estimated to be burning in Kentucky alone, a number certainly in the 'tens', these numbers become significant. It is, therefore, necessary to arrive at a better estimate of coal fires' contribution to the North American carbon budget. 


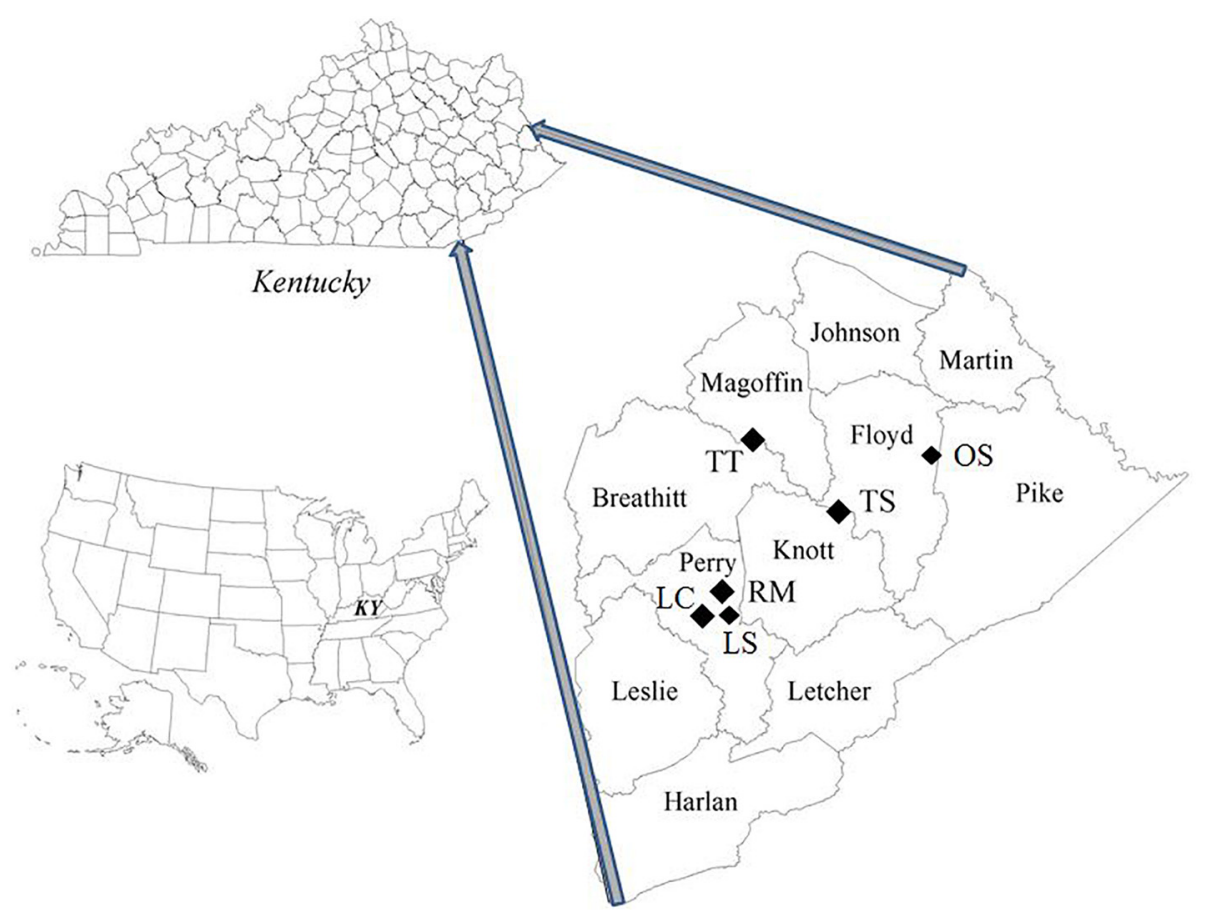

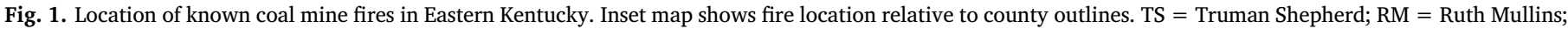
TT = Tiptop; OS = Old Smokey; LC = Laura Campbell; LS = Lotts Creek/Second Creek.

\subsection{Justification for further study of the Ruth Mullins and Tiptop coal mine fires}

In May 2009, the Kentucky coal fires team joined a national team examining fires in Wyoming (Engle et al., 2011, 2012a). This venture revealed several oversights in previous studies of fires in Kentucky including the effect of vent size on emissions estimates, and the need to complete replicate measurements. The Wyoming studies were the first to compare concentrations of greenhouse gas emissions derived from Dräger Tubes against those generated from an MX6 iBrid multigas analyzer, and to measure concentrations of more than just $\mathrm{CO}$ and $\mathrm{CO}_{2}$ in vent emissions. The i-Brid utilizes IR absorbance for $\mathrm{CO}_{2}$ and catalytic diffusion analysis for $\mathrm{CO}$ and other gases, while the Dräger Tubes rely on colorimetric response to $\mathrm{CO}$ and $\mathrm{CO}_{2}$. The Wyoming study was also the first coal fire study to utilize an Ohio Lumex RA-915 + Zeeman atomic absorption analyzer to measure $\mathrm{Hg}$ concentrations. Additionally, the Wyoming study was the first coal mine fire study in the United States to integrate both diffuse and vent emissions measurements to estimate total fire emissions.

From these endeavors, we learned that the Dräger tube measurements did not accurately estimate $\mathrm{CO}$ and $\mathrm{CO}_{2}$ concentrations in vent emissions. Dräger tube measurements of gas concentrations consistently overestimated $\mathrm{CO}$ and $\mathrm{CO}_{2}$ concentrations from small vents and underestimated the same concentrations from large vents, with error ranging $\pm 25 \%$. This implies that previously published greenhouse gas emission estimates for the Ruth Mullins fire, which has a high proportion of large vents, are underestimates. The Wyoming studies also demonstrated that other greenhouse gases and toxicants are often significant components of the vent emissions. Notably, $\mathrm{CH}_{4}$ and $\mathrm{H}_{2} \mathrm{~S}$ should be monitored and are of use in determining how the coal is burning (smoldering, flaming, etc.). The Jerome Instrument consistently overestimated $\mathrm{Hg}$ concentrations; therefore, $\mathrm{Hg}$ emissions from both fires may be lower than previously reported. The Jerome analyzer, which relies upon interaction of mercury with gold strips to change the resistance of an electrical circuit, is known to exhibit interferences from several coal combustion products including $\mathrm{H}_{2} \mathrm{~S}, \mathrm{NO}_{2}$, and thiol-bearing compounds. The Zeeman atomic absorbance based
Ohio Lumex RA-915 + instrument is free from interference from these same S- and N-bearing compounds, suggesting it may be more appropriate for quantifying $\mathrm{Hg}$ in coal fire emissions. Additionally, we found that the inclusion of diffuse emissions measurements using flux chamber-based methods significantly impacted the total greenhouse gas emission estimates for those fires (Engle et al., 2013).

Together these findings prompted us to re-examine the coal mine fires at the Ruth Mullins site and the Tiptop site. The current study aims to:

1. Produce more accurate estimates of greenhouse gas and $\mathrm{Hg}$ emissions from both fires by:

A. using an MX6 iBrid multi-gas analyzer, rather than Dräger tubes, to estimate gas concentrations,

B. determining the diffuse $\mathrm{CO}_{2}$ emissions at both sites, and

C. utilizing the Ohio Lumex Zeeman instrument to measure elemental $\mathrm{Hg}$ concentrations;

2. Visit the more accessible Ruth Mullins site repeatedly over a fourmonth period to determine if vent emissions vary significantly over that period;

3. Collect long-term carbon emission data from one vent at the Ruth Mullins fire site; and,

4. Determine an alternate means of locating the current locus of combustion, as IR imaging is not feasible at either fire site.

The present paper deals with the results of objectives 1,2 , and 4 . Results of objective 3 are discussed in Hower et al. (2011).

\section{Methods}

Emissions from the Tiptop coal fire were studied in November 2009 and compared to previous works. Emissions from the Ruth Mullins coal fire were studied in November 2009, and January, February, and August 2010 and compared to previous works. Studies of both fires utilized ground-based techniques developed by the team during work in Wyoming (Engle et al., 2011, 2012a), significantly expanding upon previous studies and refining estimates of greenhouse gas emissions. 
Table 1

Site identification, location, temperature and $\mathrm{CO}_{2}$ flux from diffuse emission measurement at the Tiptop fire.

\begin{tabular}{|c|c|c|c|c|c|c|}
\hline Site & Easting (m) & Northing (m) & $\begin{array}{l}\mathrm{CO}_{2} \\
\text { flux } \\
(\mathrm{g} / \\
\left.\mathrm{m}^{2} \mathrm{~d}\right)\end{array}$ & $\begin{array}{l}\text { Soil } \\
\text { Temp } \\
\left({ }^{\circ} \mathrm{C}\right) \text {, } \\
10 \mathrm{~cm} \\
\text { depth }\end{array}$ & $\begin{array}{l}\text { Soil } \\
\text { Temp } \\
\left({ }^{\circ} \mathrm{C}\right) \text {, } \\
\text { surface }\end{array}$ & Group \\
\hline TTF 01 & 318,089 & $4,163,274$ & 6.36 & 11.9 & 13.4 & Fire \\
\hline TTF 02 & 318,092 & $4,163,253$ & 9.13 & 15.4 & 26.4 & Fire \\
\hline TTF 03 & 318,090 & $4,163,258$ & 12.78 & 14.9 & 25.3 & Fire \\
\hline TTF 04 & 318,120 & $4,163,237$ & 8.04 & 18.5 & 25.3 & Fire \\
\hline TTF 05 & 318,122 & $4,163,246$ & -2.27 & 17.1 & 27.6 & Fire \\
\hline TTF 06 & 318,120 & $4,163,264$ & 0.31 & 18.1 & 21.9 & Fire \\
\hline TTF 07 & 318,149 & $4,163,238$ & 4.60 & 21.5 & 20.1 & Fire \\
\hline TTF 08 & 318,150 & $4,163,251$ & 8.81 & 25.4 & 30.3 & Fire \\
\hline TTF 09A & 318,150 & $4,163,265$ & 4.18 & 16.2 & 22.2 & Fire \\
\hline TTF 09B & 318,150 & $4,163,265$ & 6.58 & 16.1 & 28.3 & Fire \\
\hline TTF 09C & 318,150 & $4,163,265$ & 4.68 & 16.4 & 24.8 & Fire \\
\hline TTF 10A & 318,150 & $4,163,222$ & 4.34 & 16.6 & 14.5 & Fire \\
\hline TTF 10B & 318,150 & $4,163,222$ & 3.01 & 16.4 & 13.3 & Fire \\
\hline TTF 10C & 318,150 & $4,163,222$ & 5.55 & 16.1 & 14.8 & Fire \\
\hline TTF 11 & 318,181 & $4,163,240$ & 1.86 & 31.4 & 22.7 & Fire \\
\hline TTF 12 & 318,180 & $4,163,251$ & 5.11 & 25.7 & 27.6 & Fire \\
\hline TTF 13 & 318,182 & $4,163,221$ & 2.32 & 22.9 & 19.5 & Fire \\
\hline TTF 14 & 318,193 & $4,163,206$ & 3.12 & 18.4 & 15.8 & Fire \\
\hline TTF 15 & 318,210 & $4,163,236$ & 9.85 & 17.8 & 22.3 & Fire \\
\hline TTF 16 & 318,210 & $4,163,221$ & 3.39 & 18.5 & 19.3 & Fire \\
\hline TTF 17 & 318,210 & $4,163,210$ & 0.74 & 17.6 & 21.7 & Fire \\
\hline TTF 18 & 318,211 & $4,163,197$ & 6.75 & 16.1 & 16.8 & Fire \\
\hline TTF 20 & 318,177 & $4,163,301$ & 4.75 & 10.9 & 12.5 & Background \\
\hline TTF 21 & 318,202 & $4,163,301$ & 8.75 & 10.2 & 10.2 & Background \\
\hline TTF 22 & 318,216 & $4,163,305$ & 6.44 & 11.1 & 16.4 & Background \\
\hline TTF 23 & 318,224 & $4,163,293$ & -0.61 & 12.6 & 16.3 & Background \\
\hline TTF $24 \mathrm{~A}$ & 318,204 & $4,163,291$ & 6.88 & 11.2 & 13.4 & Background \\
\hline TTF $24 \mathrm{~B}$ & 318,204 & $4,163,291$ & 1.67 & 11.7 & 10.7 & Background \\
\hline TTF 24C & 318,204 & $4,163,291$ & 1.77 & 11.3 & 15.1 & Background \\
\hline TTF 25 & 318,206 & $4,163,261$ & 8.96 & 18.3 & 26.3 & Fire \\
\hline TTF 26A & 318,196 & $4,163,254$ & 55.62 & 27.9 & 23.7 & Fire \\
\hline TTF 26B & 318,196 & $4,163,254$ & 66.16 & 26.8 & 23.8 & Fire \\
\hline TTF 26C & 318,196 & $4,163,254$ & 72.04 & 27.4 & 21.2 & Fire \\
\hline TTF 27 & 318,184 & $4,163,267$ & 6.75 & 17.5 & 20.7 & Fire \\
\hline TTF 28 & 318,179 & $4,163,261$ & 10.72 & 19.8 & 28.0 & Fire \\
\hline TTF 29 & 318,187 & $4,163,241$ & 19.78 & 34.1 & 35.0 & Fire \\
\hline TTF 30 & 318,193 & $4,163,234$ & 12.74 & 29.3 & 23.4 & Fire \\
\hline TTF 31 & 318,177 & $4,163,236$ & 4.31 & 31.1 & 29.1 & Fire \\
\hline TTF 32 & 318,160 & $4,163,253$ & 5.93 & 29.8 & 26.7 & Fire \\
\hline TTF 33 & 318,169 & $4,163,240$ & 22.88 & 35.1 & 32.0 & Fire \\
\hline
\end{tabular}

Data available from Engle (2018).

Both fires were visited after the 2009 and 2010 studies but no additional detailed work was conducted.

Coal fire gases are transported to the surface through two primary mechanisms: advection through vents and fractures (vent emissions) and diffusion/convection through overburden (soil emissions). To inventory gases released from a site, both soil and vent emissions are measured and summed. Calculation of diffuse soil emissions requires use of geostatistical interpolation methods. Thus, the study of coal fires involves a significant geospatial component.

The techniques described below were initially field-tested at fires in the Powder River Basin (PRB) of Wyoming and were utilized in this study. Results from ground-based emission measurement methods specifically developed for coal fires were presented by Kolker et al. (2009a, 2009b) and Engle et al. (2011, 2012b, 2013).

Methods for measurement of diffuse gas emissions via flux chambers and extrapolation for coal fires are detailed in Engle et al. (2012b, 2013). Engle et al. (2013) details the sampling design, field chamber design, and geostatistical methods applied to determine estimates from the Ruth Mullin's fire. Using a custom-designed static flux chamber system (Engle et al., 2011), $49 \mathrm{CO}_{2}$ flux measurements were made at 37 sampling points at the Ruth Mullins fire, including four points (six measurements) outside of the active coal fire area. At the Tiptop fire, a total of $40 \mathrm{CO}_{2}$ flux measurements were made at 27 locations, including five points (seven measurements) outside of the active coal fire area. Corresponding results are summarized in Table 1 (Engle, 2018). Estimates of the total diffuse emission and uncertainty were scaled across the fire using sequential Gaussian simulation (see Engle et al., 2013 for details); results were corrected for soil respiration-related emissions using the measurements taken outside the active coal fire area.

At each fire site, coordinates of each measurement point for diffuse emissions were imported into ArcGIS ${ }^{\circledast}$ and plotted in WGS 1984 UTM $17 \mathrm{~N}$ projection. The image of the $\mathrm{CO}_{2}$ diffuse emissions generated using the methods of Engle et al. (2013) was imported, georeferenced, and matched to the measurement points for each fire. A Kentucky base map layer was added, as was a dBase topographic file for each quadrangle studied to show the footprint of the fire site in relation to topography. This also allowed an estimate of overburden volume to be calculated, as the combusting coals are contained in near-horizontal strata at an elevation of ca. $430 \mathrm{~m}$.

In January 2010, the perimeter of the zone of melted snow overlying the fire was mapped using a Trex GPS unit. A polygon was generated using these points and overlain on the maps of the diffuse emissions.

For vent emission measurements the gas flow rate, air temperature, relative humidity, and barometric pressure were measured in at least five locations within each vent using a Flow Kinetics FKT 1DP1A-SV flow meter attached to an S-type pitot tube. In the case of large vents, the emission area was broken into smaller areas and five sets of measurements were taken from each. Within each vent area, concentrations of $\mathrm{CO}_{2}, \mathrm{CO}, \mathrm{CH}_{4}$, and $\mathrm{H}_{2} \mathrm{~S}$ were measured using an Industrial Scientific MX6 iBrid combustion gas analyzer and $\mathrm{Hg}$ concentrations were determined using an Ohio Lumex Zeeman atomic absorption spectrometer. The MX6 combustion gas analyzer was calibrated with zero and span standards prior to and after the field campaign; previous work in the PRB has shown that no significant drift is observed in this instrument during a three-day field campaign (Engle et al., 2012a). The Lumex $\mathrm{Hg}$ analyzer was calibrated daily using its internal standard. Vent fluxes for specific gases $\left(Q_{i}\right)$ from individual vents were determined by:

$\mathrm{Q}_{\mathrm{i}}=\mathrm{C}_{\mathrm{i}} \mathrm{va}$

where $C_{i}$ is the concentration of gas $i, v$ is the average velocity of the coal gas exiting the vent, and a is vent area. Results are summarized in Table 2.

Vent gases were sampled for VOCs at selected vent locations. Samples were collected in pre-evacuated, electropolished stainless-steel gas-sampling canisters. Samples were analyzed for carbon-bearing gases (i.e., $\mathrm{CO}, \mathrm{CO}_{2}$, carbonyl sulfide, dimethylsulfide, and carbon disulfide), C1-C7 aliphatic hydrocarbons, and single-ring aromatics (BTEX, etc.) on a gas chromatographic system in the Rowland-Blake Group laboratory at the University of California - Irvine. Analytical methods and quality control methods are described in Barletta et al. (2008) and Coleman et al. (2001). Results are summarized in Table 3.

Bulk minerals collected from the Ruth Mullins fire were analyzed chemically at the University of Kentucky Center for Applied Energy Research (CAER) and optically at Morehead State University. Samples for optical analysis were separated from the associated rock, twigs, and roots, crushed to -140 mesh (finer than $106 \mu \mathrm{m}$ ), mounted in Cargille Meltmount ${ }^{\circledR}$ thermoplastic resin, and examined on a Nikon Optiphot ${ }^{\circledR}$ petrographic microscope. Photomicrographs were obtained using a Nikon digital camera. Independent of this study, nanominerals and nanocarbons from this fire were detailed in Silva et al. (2011a, 2011b).

$\mathrm{X}$-ray diffraction (XRD) patterns were used to identify the mineralogy of samples collected at vents 3 and 5 of the Ruth Mullins fire; vent minerals were not observed at the Tiptop fire during any of the sampling events. Mineralogy data were obtained at the University of Georgia, Athens, where the samples were first ground to powder in air 


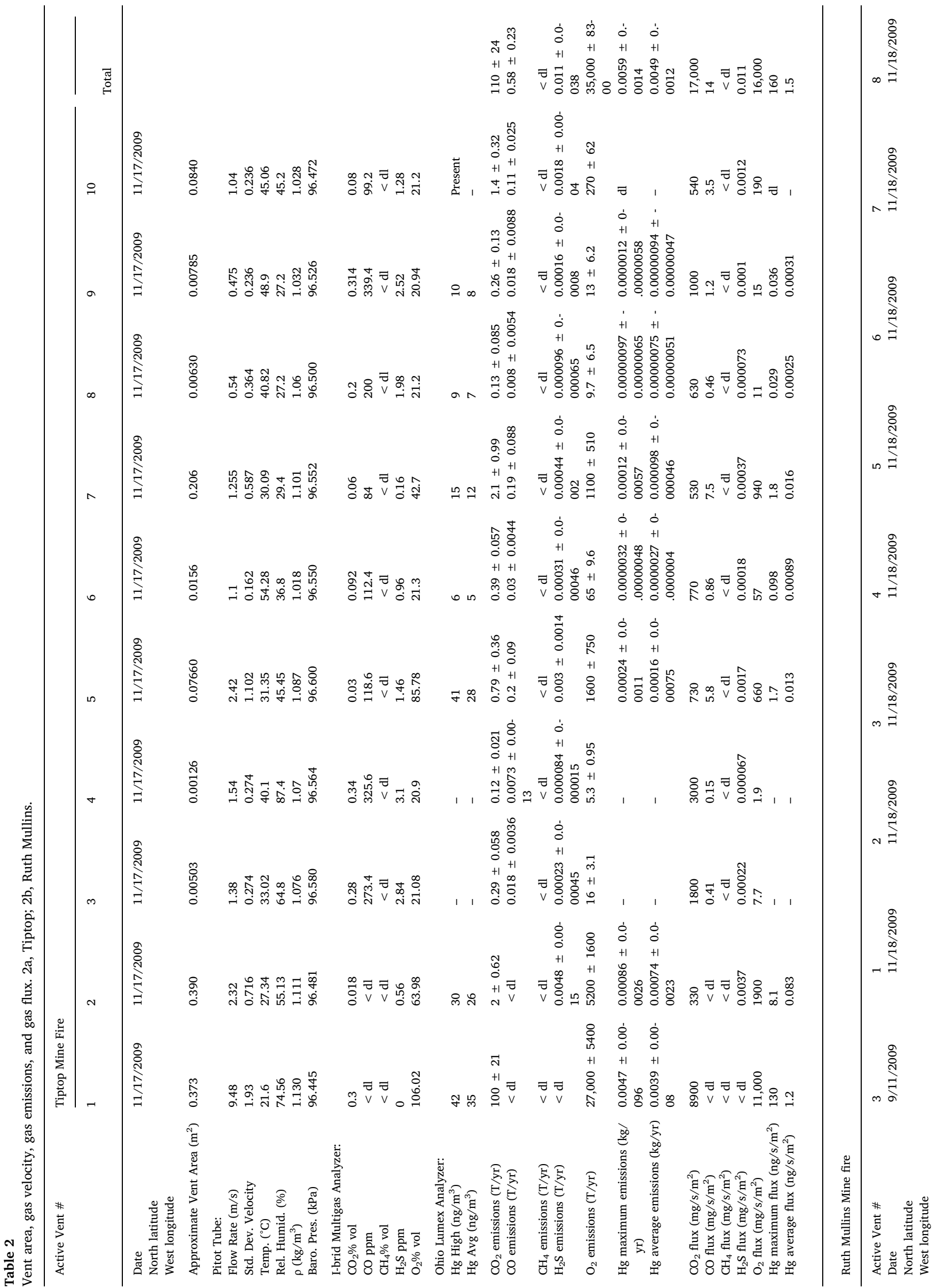




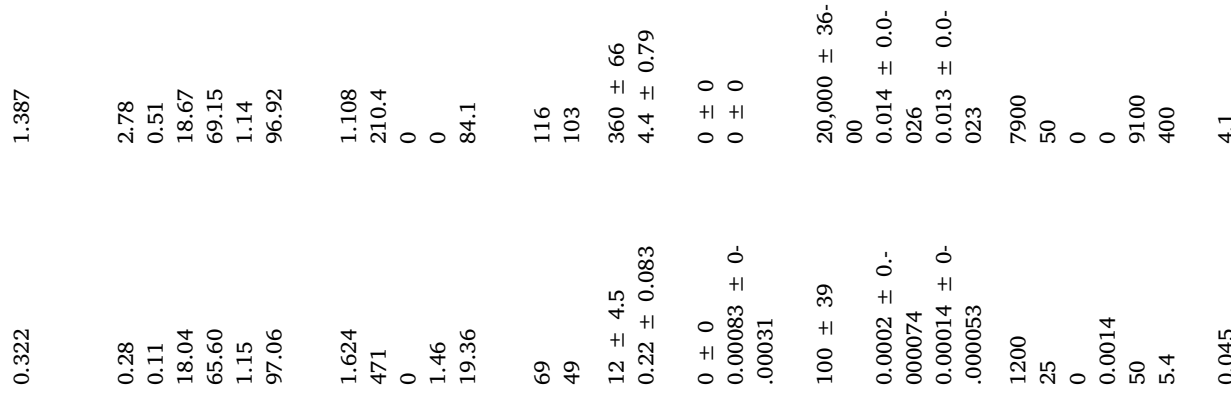

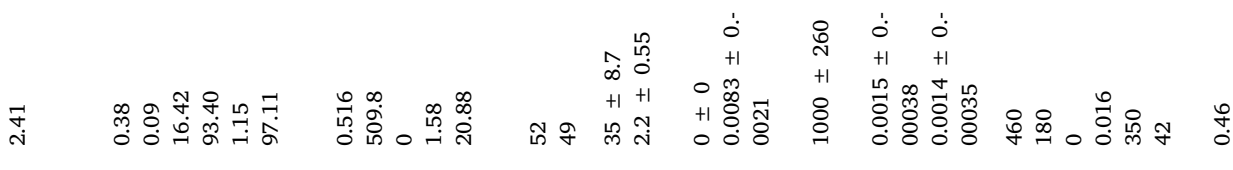

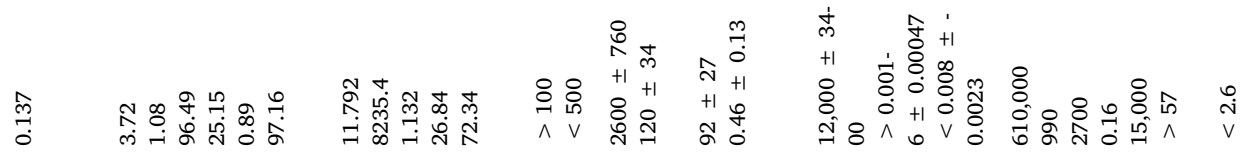

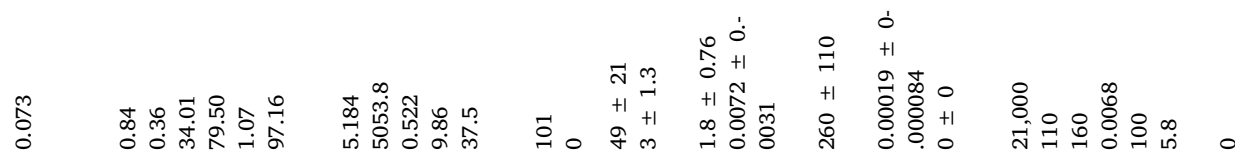

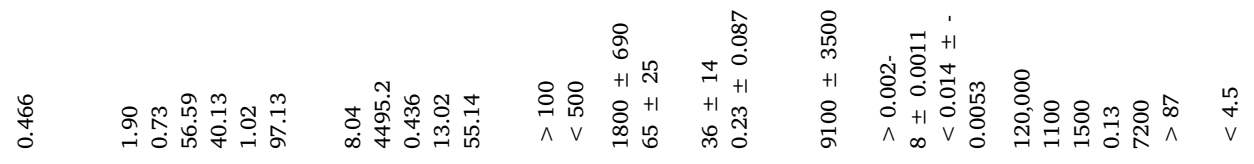

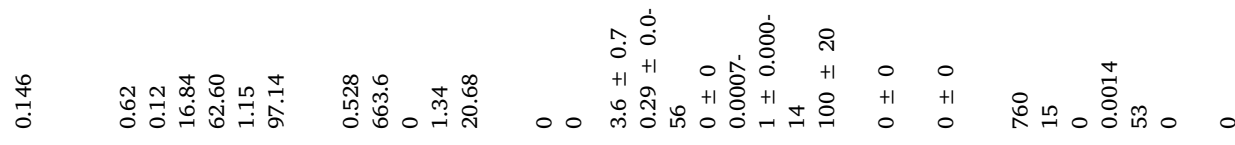

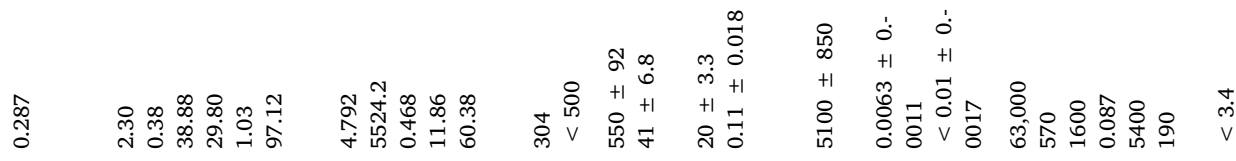

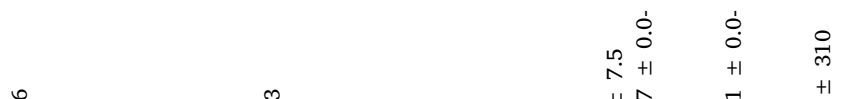

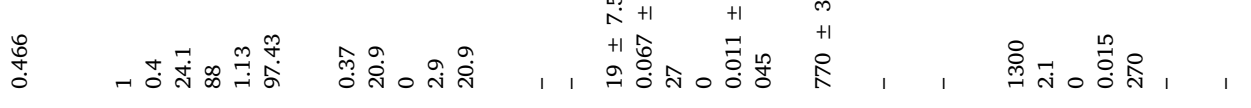

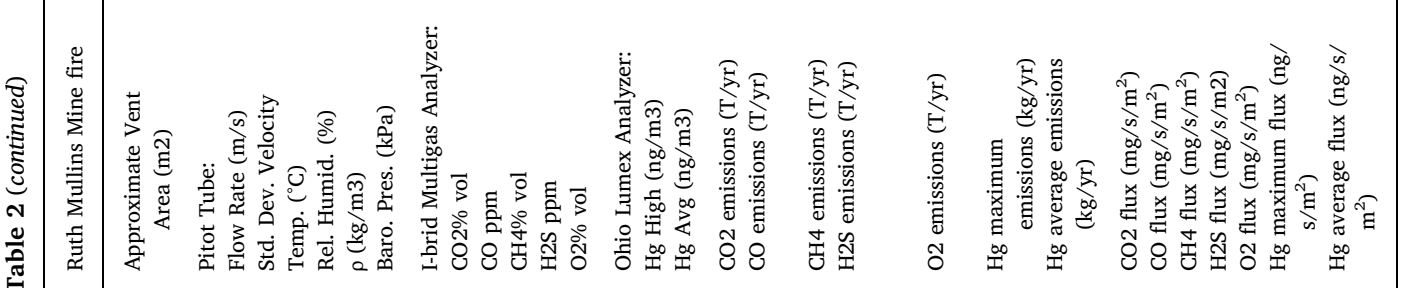




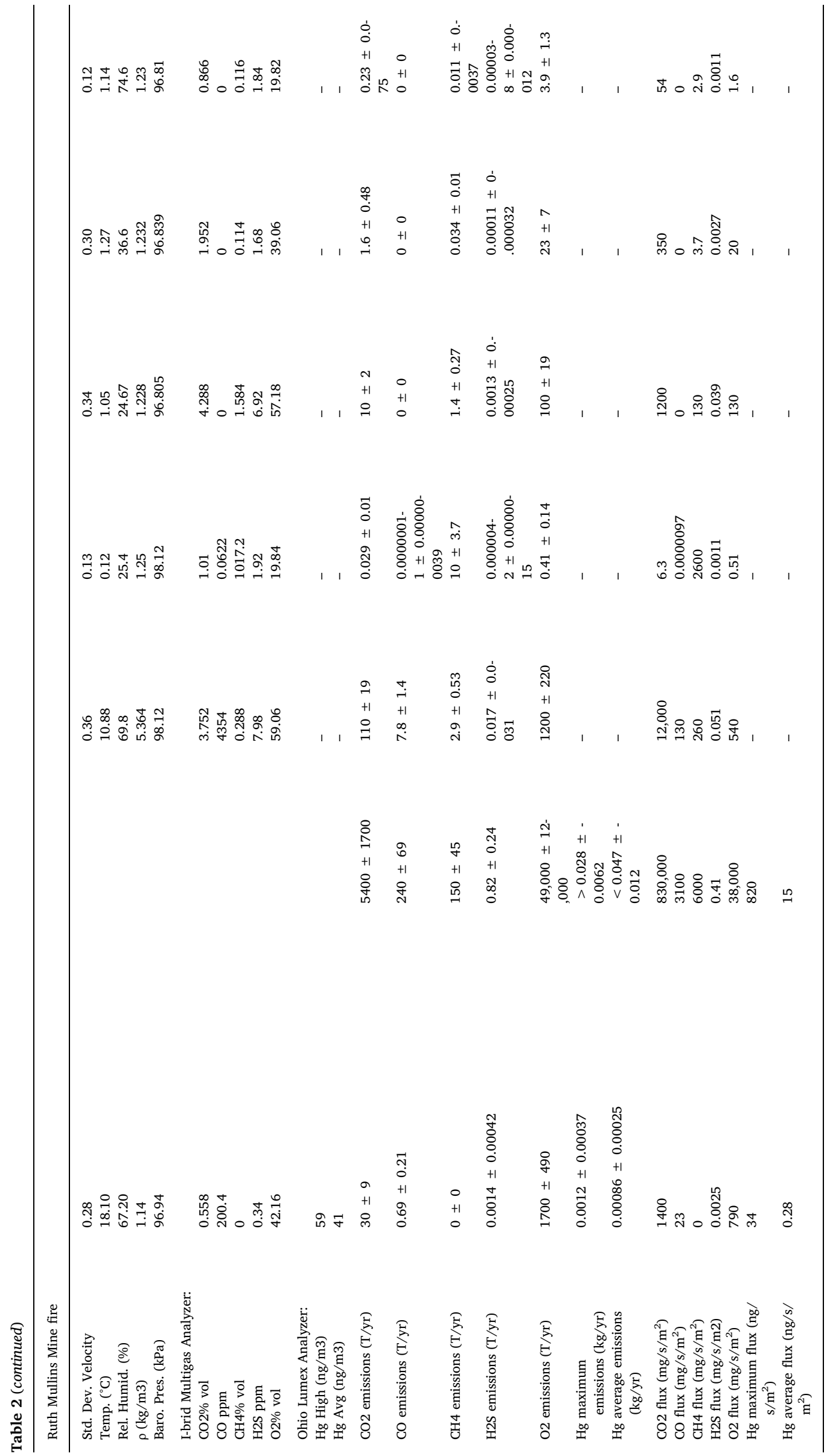


Table 3

Aliphatic hydrocarbons and benzene-toluene-ethylbenzene-xylene aromatics in vent emissions at the Ruth Mullins fire.

\begin{tabular}{|c|c|c|c|c|c|c|c|c|c|c|}
\hline & & & Vent $1 b$ & Vent 3a & Vent 6 & Vent 9 & Vent 1 & Vent $3 b$ & Vent 4 & Vent 5 \\
\hline & & & 18-Nov-09 & 18-Nov-09 & 18-Nov-09 & 18-Nov-09 & 12-Jan-10 & 12-Jan-10 & 12-Jan-10 & 12-Jan-10 \\
\hline Carbon monoxide & $\mathrm{CO}$ & ppbv & 270,000 & $1,070,000$ & 757,000 & 63,600 & 15,600 & $1,170,000$ & 272 & 610,000 \\
\hline Carbon dioxide & $\mathrm{CO}_{2}$ & ppmv & 6560 & 23,700 & 6560 & 2110 & 603 & 70,500 & 410 & 38,200 \\
\hline Carbonyl sulfide & OCS & pptv & 266,000 & 1390 & 373 & 5270 & 4040 & 90,600 & 568 & 78,700 \\
\hline Carbon disulfide & $\mathrm{CS}_{2}$ & pptv & 102,000 & 634 & 97 & 24,300 & 1460 & 1550 & 25 & 1030 \\
\hline \multicolumn{11}{|l|}{ Aliphatic compounds } \\
\hline Methane & $\mathrm{CH}_{4}$ & ppmv & 415 & 11 & 111 & 421 & 5 & 220 & 2 & 84 \\
\hline Ethane & $\mathrm{C}_{2} \mathrm{H}_{6}$ & pptv & $36,400,000$ & 328,000 & $8,870,000$ & $1,790,000$ & 215,000 & $8,740,000$ & 10,700 & $5,940,000$ \\
\hline Ethene & $\mathrm{C}_{2} \mathrm{H}_{4}$ & pptv & $1,690,000$ & 175,000 & 461,000 & 568,000 & 21,500 & $2,590,000$ & 917 & $1,210,000$ \\
\hline Ethyne & $\mathrm{C}_{2} \mathrm{H}_{2}$ & pptv & 67,000 & 7940 & 22,500 & 24,200 & 2820 & 176,000 & 828 & 75,200 \\
\hline Propane & $\mathrm{C}_{3} \mathrm{H}_{8}$ & pptv & $8,240,000$ & 54,800 & $2,180,000$ & 362,000 & 62,600 & $1,870,000$ & 4760 & $1,280,000$ \\
\hline Propene & $\mathrm{C}_{3} \mathrm{H}_{6}$ & pptv & 889,000 & 11,700 & 214,000 & 31,000 & 9880 & 286,000 & 246 & 225,000 \\
\hline i-Butane & $\mathrm{C}_{4} \mathrm{H}_{10}$ & pptv & 781,000 & 4980 & 212,000 & 36,200 & 23,000 & 185,000 & 690 & 124,000 \\
\hline n-Butane & $\mathrm{C}_{4} \mathrm{H}_{10}$ & pptv & $2,110,000$ & 12,600 & 609,000 & 89,100 & 21,900 & 500,000 & 1650 & 362,000 \\
\hline trans-2-Butene & $\mathrm{C}_{4} \mathrm{H}_{8}$ & pptv & 150,000 & 333 & 31,900 & 1930 & 1550 & 15,700 & 18 & 24,800 \\
\hline cis-2-Butene & $\mathrm{C}_{4} \mathrm{H}_{8}$ & pptv & 105,000 & 226 & 22,800 & 1090 & 1140 & 10,100 & 15 & 17,200 \\
\hline i-Butene & $\mathrm{C}_{4} \mathrm{H}_{8}$ & pptv & 113,000 & 216 & 22,800 & 848 & 1360 & 6890 & 45 & 15,300 \\
\hline 1-Butene & $\mathrm{C}_{4} \mathrm{H}_{8}$ & pptv & 129,000 & 360 & 26,500 & 1240 & 1970 & 6140 & 60 & 15,000 \\
\hline 1,3-Butadiene & $\mathrm{C}_{4} \mathrm{H}_{6}$ & pptv & 23,800 & 343 & 6060 & 462 & 299 & 12,800 & $\mathrm{dl}$ & 8030 \\
\hline 2-methyl-1,3-butadiene (isoprene) & $\mathrm{C}_{5} \mathrm{H}_{8}$ & pptv & 7670 & 173 & 1610 & 154 & 116 & 1710 & 10 & 1480 \\
\hline i-Pentane & $\mathrm{C}_{5} \mathrm{H}_{12}$ & pptv & 527,000 & 3110 & 132,000 & 21,100 & 68,000 & 93,900 & 481 & 66,100 \\
\hline n-Pentane & $\mathrm{C}_{5} \mathrm{H}_{12}$ & pptv & $1,020,000$ & 5170 & 291,000 & 36,600 & 14,900 & 220,000 & 500 & 173,000 \\
\hline 1-Pentene & $\mathrm{C}_{5} \mathrm{H}_{10}$ & pptv & 50,900 & 80 & 9740 & 264 & 526 & 1350 & $\mathrm{dl}$ & 5220 \\
\hline n-Hexane & $\mathrm{C}_{6} \mathrm{H}_{14}$ & pptv & 598,000 & 3010 & 172,000 & 18,300 & 3400 & 130,000 & 211 & 109,000 \\
\hline n-Heptane & $\mathrm{C}_{7} \mathrm{H}_{16}$ & pptv & 357,000 & 1590 & 106,000 & 9060 & 5140 & 88,000 & 92 & 74,400 \\
\hline n-Octane & $\mathrm{C}_{8} \mathrm{H}_{18}$ & pptv & 315,000 & 1230 & 69,100 & 4520 & 2460 & 34,200 & 37 & 31,400 \\
\hline n-Nonane & $\mathrm{C}_{9} \mathrm{H}_{20}$ & pptv & 231,000 & 1080 & 43,700 & 2270 & 2110 & 20,000 & 25 & 20,000 \\
\hline 2,3-Dimethylbutane & $\mathrm{C}_{6} \mathrm{H}_{14}$ & pptv & 36,900 & 147 & 9350 & 1580 & 449 & 5150 & 12 & 3840 \\
\hline 2-Methylpentane & $\mathrm{C}_{6} \mathrm{H}_{14}$ & pptv & 243,000 & 1440 & 66,100 & 9290 & 2580 & 36,400 & $\mathrm{dl}$ & 29,400 \\
\hline 3-Methylpentane & $\mathrm{C}_{6} \mathrm{H}_{14}$ & pptv & 88,300 & 450 & 22,700 & 3840 & 1090 & 13,500 & 39 & 10,200 \\
\hline 2-Methylhexane & $\mathrm{C}_{7} \mathrm{H}_{16}$ & pptv & 73,300 & 532 & 18,500 & 2920 & 1270 & 11,500 & 80 & 9970 \\
\hline 3-Methylhexane & $\mathrm{C}_{7} \mathrm{H}_{16}$ & pptv & 83,300 & 424 & 18,800 & 2990 & 1650 & 12,400 & 86 & 11,400 \\
\hline 2,4-Dimethylpentane & $\mathrm{C}_{7} \mathrm{H}_{16}$ & pptv & 53,500 & 247 & 15,700 & 2060 & 656 & 7260 & 46 & 5850 \\
\hline \multicolumn{11}{|l|}{ Aromatic compounds } \\
\hline Benzene & $\mathrm{C}_{6} \mathrm{H}_{6}$ & pptv & $1,440,000$ & 31,000 & 328,000 & 31,200 & 34,900 & $1,110,000$ & 744 & 736,000 \\
\hline Toluene & $\mathrm{C}_{7} \mathrm{H}_{8}$ & pptv & 646,000 & 3180 & 120,000 & 2840 & 37,000 & 69,500 & 632 & 149,000 \\
\hline Ethylbenzene & $\mathrm{C}_{8} \mathrm{H}_{10}$ & pptv & 101,000 & 377 & 15,000 & 650 & 3190 & 5160 & 107 & 19,000 \\
\hline m\&p-Xylene & $\mathrm{C}_{8} \mathrm{H}_{10}$ & pptv & 348,000 & 1380 & 53,400 & 2240 & 8640 & 15,900 & 452 & 54,300 \\
\hline o-Xylene & $\mathrm{C}_{8} \mathrm{H}_{10}$ & pptv & 145,000 & 542 & 19,800 & 795 & 3550 & 4740 & 140 & 22,100 \\
\hline
\end{tabular}

with an agate mortar and pestle. Each powder was then mounted on a $40 \times 30 \mathrm{~mm}$ petrographic glass slide. All powder XRD data were obtained using a Bruker D8 Advance X-ray diffractometer. Instrument operating conditions included the following: CoKa radiation (generated at $40 \mathrm{kV}$ and $40 \mathrm{~mA}$ ), a $250-\mathrm{mm}$ goniometer radius, $1^{\circ} / 2^{\circ}$ primary/ scattering slits, $0.3^{\circ}$ receiving slit, primary soller slit, and a LynxEye ${ }^{\circledast}$ 192 silicon strip position sensitive detector. Data were collected using a scan rate of $0.1 \mathrm{~s}$ per step with a step increment of $0.01^{\circ} 2 \theta$.

Diffractogram peaks were externally calibrated with reference to the National Institute of Standards and Technology (NIST) corundum standard, SRM1976. Peak positions were best matched with patterns from the International Centre for Diffractions Data - Powder Diffraction File (ICDD-PDF) using Bruker's Eva ${ }^{\circledast}$ evaluation software. ICDD-PDF card numbers were assigned to our best-fit diffractograms.

Each sample was examined for high-resolution imaging and compositional purposes using Scanning Electron Microscopy/Energy Dispersive X-Ray Spectroscopy (SEM/EDS). Freshly fractured surfaces were prepared and mounted onto aluminum stubs using carbon-coated tape. Data were collected using a Zeiss 1450EP SEM/EDS instrument located in the University of Georgia Center for Advanced Ultrastructural Research (CAUR) (http://www.uga.edu/caur/). The instrument is a variable pressure tungsten filament SEM with a sample chamber that allows imaging from high vacuum mode to $2800 \mathrm{~Pa}$. It is equipped with a Debens peltier stage, water injection system, and an Oxford INCA EDS system.

Tar samples were collected in sterile glass jars at the Ruth Mullins fire and sent to NewFields Environmental Forensics for high-resolution hydrocarbon fingerprinting using a modification of EPA Methods 8015 and $8270 \mathrm{C}$. This was accomplished with a gas chromatograph equipped with a flame ionization detector (GC/FID) for hydrocarbons in the 9 to 44 carbon molecular weight range and a GC equipped with a mass spectrometer (GC/MS) for polycyclic aromatic hydrocarbons (PAHs) with 2 to 7 rings (Stout and Emsbo-Mattingly, 2008; Emsbo-Mattingly and Stout, 2011). The tar results are presented in Table 4.

To investigate possible controls and inter-relationships between conditions and compounds in the vent emissions, data from both sites were examined using principal component analysis (PCA) in Aabel ${ }^{\mathrm{TM}} 3$ (Gigawiz ${ }^{\mathrm{TM}}$ Software). Included variables were flow rate, gas temperature, barometric pressure, relative humidity, and $\log _{10}$ concentrations of $\mathrm{CH}_{4}, \mathrm{CO}, \mathrm{CO}_{2}$, and $\mathrm{H}_{2} \mathrm{~S}$. A portion of the $\mathrm{CH}_{4}(64 \%)$, $\mathrm{CO}(20 \%)$, and $\mathrm{H}_{2} \mathrm{~S}(8 \%)$ data were reported below the method detection limit; estimated values were determined using an isometric-log ratio based expectation-maximum-likelihood estimation algorithm (Hron et al., 2010) and subsequently imputed. Eigen decomposition was completed using the covariance matrix of the scaled dataset.

\section{Results and discussion}

\subsection{Tiptop}

Based on the vent data collected and presented in Table 2, Tiptop is emitting $\pm 107.48 \mathrm{~T} / \mathrm{yr} \mathrm{CO} 2 \mathrm{yr}, \pm 0.58 \mathrm{~T} / \mathrm{yr} \mathrm{CO}, \pm 0.01 \mathrm{~T} / \mathrm{yr} \mathrm{H}_{2} \mathrm{~S}$, little 
Table 4

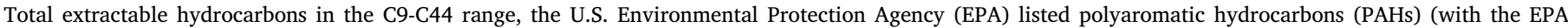

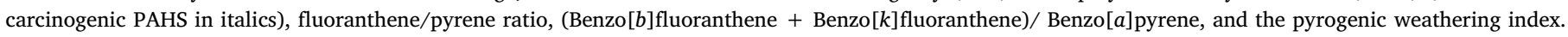

\begin{tabular}{|c|c|c|c|c|}
\hline \multirow[t]{2}{*}{ Compound: } & \multirow{2}{*}{$\begin{array}{l}\text { Sample ID: } \\
\text { Source: }\end{array}$} & \multirow{2}{*}{$\begin{array}{l}\text { RM Tar } \\
\text { Vent 1, part B }\end{array}$} & \multirow{2}{*}{$\begin{array}{l}\text { RM 5A } \\
\text { Vent 5, part A }\end{array}$} & \multirow{2}{*}{$\begin{array}{l}\text { RM 5D } \\
\text { Vent 5, part D }\end{array}$} \\
\hline & & & & \\
\hline Total Extractable Hydrocarbons (TEH, C9-C44) & $\mathrm{mg} / \mathrm{kg}$ & 639,000 & 117,000 & 634,000 \\
\hline \multicolumn{5}{|l|}{ EPA PAHs: } \\
\hline Naphthalene (NO) & $\mathrm{mg} / \mathrm{kg}$ & 10.3 & 3.08 & 52.6 \\
\hline Acenaphthylene (AY) & $\mathrm{mg} / \mathrm{kg}$ & 134 & 0.333 & 1.77 \\
\hline Acenaphthene (AE) & $\mathrm{mg} / \mathrm{kg}$ & 1.05 & 0.28 & 4.27 \\
\hline Fluorene (FO) & $\mathrm{mg} / \mathrm{kg}$ & 25.8 & 3.32 & 297 \\
\hline Phenanthrene (PO) & $\mathrm{mg} / \mathrm{kg}$ & 823 & 144 & 3820 \\
\hline Anthracene (AO) & $\mathrm{mg} / \mathrm{kg}$ & 1220 & 28.5 & 1990 \\
\hline Fluoranthene (FLO) & $\mathrm{mg} / \mathrm{kg}$ & 11,900 & 146 & 3900 \\
\hline Pyrene (PYO) & $\mathrm{mg} / \mathrm{kg}$ & 12,900 & 182 & 6230 \\
\hline Benz[a]anthracene (BAO) (tetracene) & $\mathrm{mg} / \mathrm{kg}$ & 19,700 & 182 & 5180 \\
\hline Chrysene (CO) & $\mathrm{mg} / \mathrm{kg}$ & 17,900 & 918 & 5060 \\
\hline Benzo[b]fluoranthene (BBF) & $\mathrm{mg} / \mathrm{kg}$ & 11,900 & 585 & 717 \\
\hline Benzo[k]fluoranthene (BJKF) & $\mathrm{mg} / \mathrm{kg}$ & 13,600 & 308 & 438 \\
\hline Benzo[a]pyrene (BAP) & $\mathrm{mg} / \mathrm{kg}$ & 14,700 & 221 & 500 \\
\hline Indeno $[1,2,3-c d]$ pyrene (IND) & $\mathrm{mg} / \mathrm{kg}$ & 5130 & 76.2 & 55.2 \\
\hline Dibenz $[a, h]$ anthracene (DA) & $\mathrm{mg} / \mathrm{kg}$ & 2490 & 36.9 & 28.6 \\
\hline Benzo $[g, h, i]$ perylene (GHI) & $\mathrm{mg} / \mathrm{kg}$ & 3710 & 172 & 88.5 \\
\hline \multirow[t]{2}{*}{ Sum of EPA PAHs: } & $\mathrm{mg} / \mathrm{kg}$ & 116,000 & 3010 & 28,400 \\
\hline & $\%$ & $18 \%$ & $3 \%$ & $4 \%$ \\
\hline FLO/PYO & Unitless & 0.922 & 0.802 & 0.626 \\
\hline$(\mathrm{BBF}+\mathrm{BJKF}) / \mathrm{BAP}$ & Unitless & 1.73 & 4.04 & 2.31 \\
\hline Degree of pyrogenic weathering (PWI) & & $\mathrm{NO}<\mathrm{PO}<\mathrm{PYO}$ & $\mathrm{NO}<\mathrm{PO}<\mathrm{PYO}$ & $\mathrm{NO}<\mathrm{PO}<\mathrm{PYO}$ \\
\hline
\end{tabular}

[RM, Ruth Mullins].

to no $\mathrm{CH}_{4}$ per year, and a maximum of $5.9 \mathrm{~g} \mathrm{Hg} / \mathrm{yr}$. High $\mathrm{CO}_{2}$ emissions relative to $\mathrm{CO}$ and $\mathrm{CH}_{4}$ are indicative of near-complete combustion, although the quantities emitted also indicate that relatively little coal is burning. This is not surprising, as the seam has been auger-mined and relatively little coal remains.

Little vent activity has been observed at Tiptop since November 2009. ${ }^{7}$ It is possible that this fire is nearing the end of its lifespan. The Tiptop fire will be limited by the footprint of the ridge it is burning through. It was advancing toward the nose of the ridge in the two years it was monitored, and evidence of past fire activity in the area indicates that it has been advancing in this direction for some time.

A map of interpolated diffuse $\mathrm{CO}_{2}$ emissions at Tiptop indicates that the main locus of combustion is near the east end of the ridge (Fig. 2), which is adjacent to an area of auger holes. Based on results from 100 sequential Gaussian simulations, background-corrected diffuse $\mathrm{CO}_{2}$ emissions at Tiptop are estimated at 3.3-17.6 T/yr (5th and 95th percentile, respectively), with a median of $10.3 \mathrm{~T} / \mathrm{yr}$. This quantity is significantly smaller than the vent emissions. Total emissions for this fire, based on data from November 2009 indicate that it is producing approximately $118 \mathrm{~T} / \mathrm{yr}$ of $\mathrm{CO}_{2}$.

We may see more activity as the burn front reaches the auger holes to the west of its present location (Fig. 3). That will, however, likely be the final phase of the Tiptop fire; with near-complete combustion occurring, it is unlikely that this fire will continue burning once the remaining coal surrounding the auger holes is consumed.

\subsection{Ruth Mullins}

The Ruth Mullins fire site consisted of (1) three boreholes along state highway KY-80, drilled by the Kentucky Department of Transportation to determine if the seam and/or abandoned mine works

\footnotetext{
${ }^{7}$ Hower observed minor activity on a November 2012 trip to the site. He was told that the fire was still active in March 2014 (personal communication with company personnel).
}

extend beneath the road, and (2) a series of nine vents opening through slumps and slides in the ridge. Along some of these latter vents, rather unusual fire features may be seen, such as tar-coated spider webs and, during the winter months, tar-coated icicles. The Ruth Mullins fire site was visited three times over the course of this study: November 2009, January 2010, and February 2010. The bulk of the data presented in this paper was collected in November 2009; selected vents were visited in January and February 2010, as conditions at the face allowed. The snowmelt polygon was mapped in January 2010.

Based on the November 2009 data, the Ruth Mullins coal mine fire was projected to be emitting $\pm 5400 \mathrm{~T} / \mathrm{yr} \quad \mathrm{CO}_{2}, \pm 240 \mathrm{~T} / \mathrm{yr}$ $\mathrm{CO}, \pm 150 \mathrm{~T} / \mathrm{yr} \mathrm{CH} 4, \pm 0.81 \mathrm{~T} / \mathrm{yr} \mathrm{H}_{2} \mathrm{~S}$, and a maximum of $2.7 \mathrm{~g} / \mathrm{yr} \mathrm{Hg}$ (Table 2). The high values of $\mathrm{CO}$ and $\mathrm{CH}_{4}$ relative to $\mathrm{CO}_{2}$ values indicate that, unlike the Tiptop fire, some degree of incomplete combustion is occurring at the Ruth Mullins fire. During the January and February 2010 sampling trips, only vents 1 and 2 were reliably accessible. Variations in emissions were recorded during those visits (Table 2). The overall vent emissions dropped significantly in January and February. For example, vent $\mathrm{CO}_{2}$ emissions in January and February of 2010 were $>98 \%$ lower than those for November 2009. This indicates that fluctuations in vent emission from coal fires are more complex than previously thought. We hypothesize that the observed variations are driven by complex forcing mechanisms including: 1) seasonal variations including temperature and quantity of moisture entering the system; 2) air pressure variations; 3 ) collapse of conduits leading to the vents resulting in cessation or reduction in venting from specific locations; and 4) movement of the fire front. It is suspected that while a combination of all four factors is acting on the fire system, the variations are largely driven by factors 1 and 2, based on results of longterm monitoring of $\mathrm{CO}$ emissions (Hower et al., 2011).

A map of the diffuse $\mathrm{CO}_{2}$ emissions recorded above the Ruth Mullins coal mine fire shows that the greatest diffuse emissions occur near the center of the study area (Fig. 4), with a median flux of $5.9 \mathrm{~g} \mathrm{CO}_{2} / \mathrm{m}^{2} \mathrm{~d}$ being emitted across the fire. When the fire "melt zone" mapped in January 2010 is overlain atop this image, it shows reasonable 


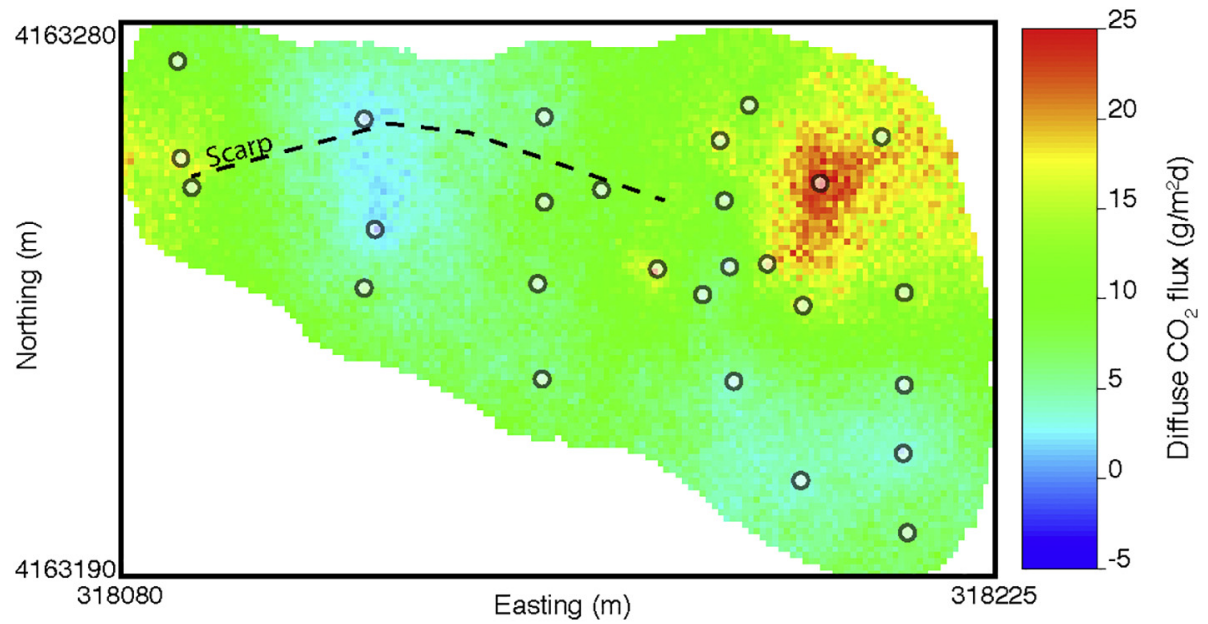

Fig. 2. False color heat maps of showing the mean diffuse $\mathrm{CO}_{2}$ fluxes from the Tiptop fire for each node in the study based on 100 realizations from sequential Gaussian simulation.
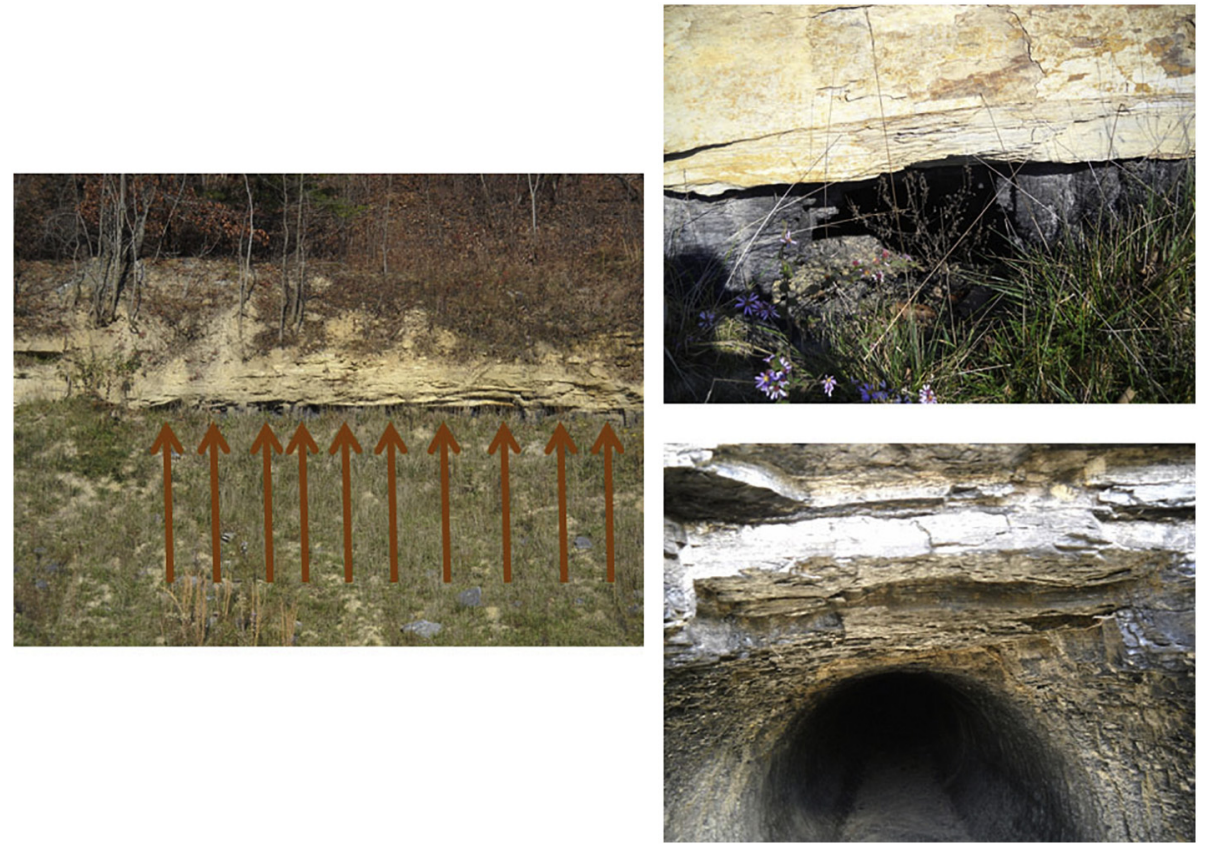

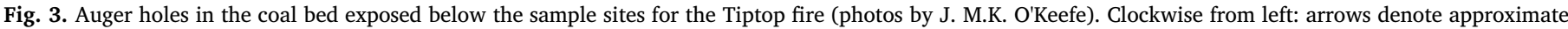
locations of the auger holes; collapsed auger hole; round auger hole.

alignment with the areas of greatest diffuse emissions mapped in November 2009. Together, the two provide a reasonable estimate of the Fall 2009/Winter 2010 location of the fire. The areas of greatest diffuse emissions also correlate well with the trend of collapsed mine portals that were visible during the 2008 visit, locations of which were recorded in field notes at that time (Fig. 4). This suggests that the majority of combustion is occurring along the faces of abandoned mine works. This observation is not unexpected, as more oxygen is likely to be present in these locations and fractures in the overlying rocks are most likely to develop along pre-existing zones of weakness caused by mine roof subsidence. Based on the November 2009 sampling, Engle et al. (2013) estimated total diffuse $\mathrm{CO}_{2}$ emissions for the Ruth Mullins coal fire of 11-42 $\mathrm{T} / \mathrm{yr} \mathrm{CO}_{2}$ (5th and 95th percentile, respectively) with a median of $25 \mathrm{~T} / \mathrm{yr} \mathrm{CO}_{2}$, with total $\mathrm{CO}_{2}$ emissions of approximately $5400 \mathrm{~T} / \mathrm{yr}$. The diffuse emissions at Ruth Mullins are, in general, two orders of magnitude lower than the vent emissions. By comparison, in coal fires in Wyoming, vent and diffuse emissions are generally of the same order of magnitude (Engle et al., 2011, 2012a). We think the

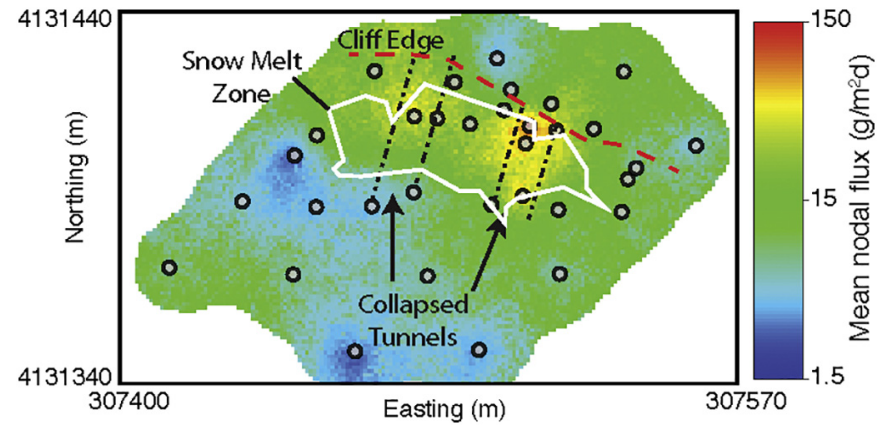

Fig. 4. False color heat maps of showing the mean diffuse $\mathrm{CO}_{2}$ fluxes from the Ruth Mullins fire for each node in the study based on 100 realizations from sequential Gaussian simulation. Also shown are the location of the highwall, the January 2010 snowmelt boundary, and the location of collapsed mine tunnels. Modified from Engle et al. (2013). 


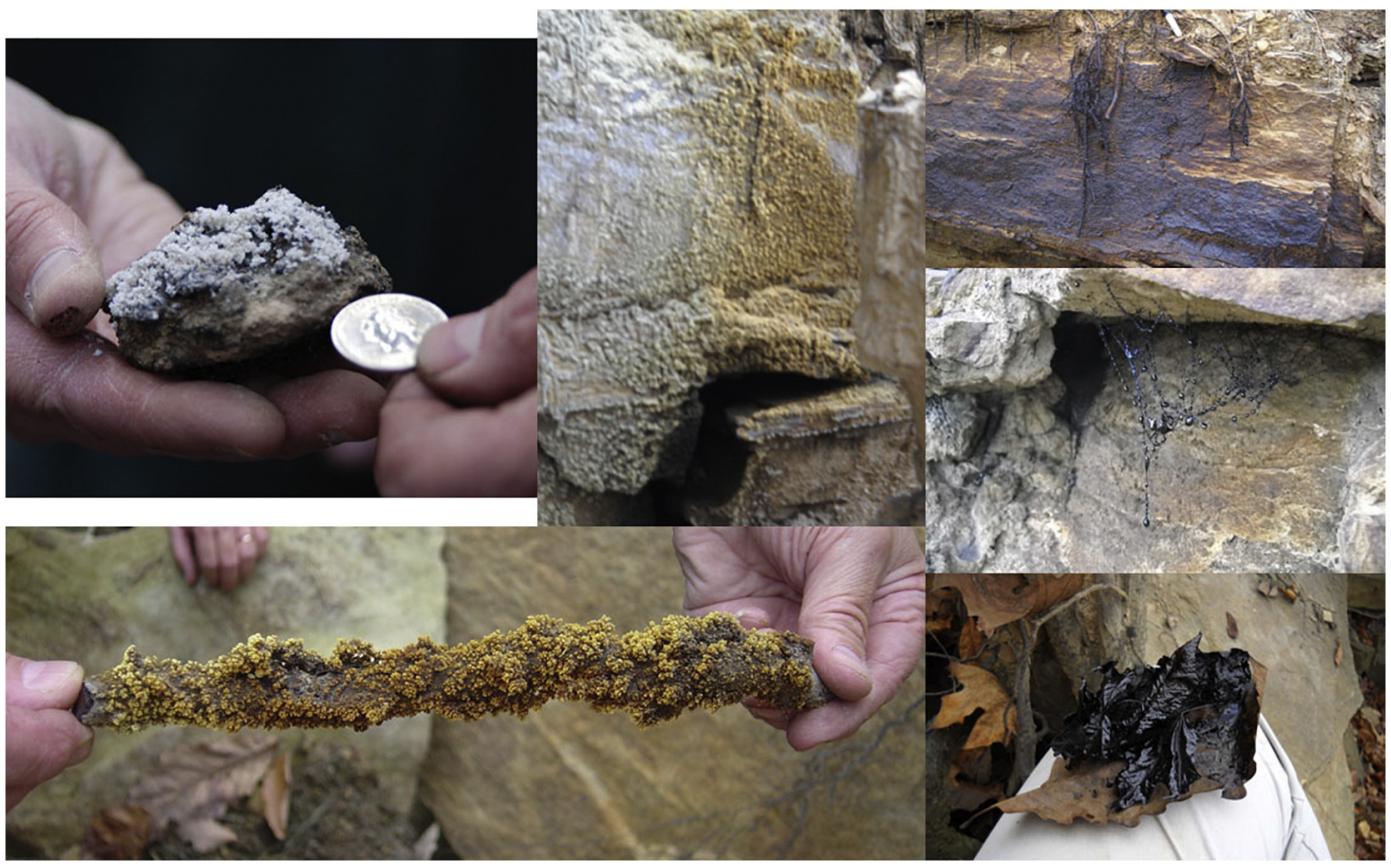

Fig. 5. Minerals and tars at the Ruth Mullins fire (photos by J.M.K. O'Keefe). Counterclockwise from lower left: tar-infused salammoniac on twig, salammoniac on rock fragment, minerals on rock face at vent, tar along rock face at vent, tar on spider web, and tar on leaf.

lower diffuse-to-vent emissions at the Ruth Mullins fire are due to two factors: 1) low permeability, thick quartz- and calcite-cemented sandstone and shale overburden is reducing diffusion; and 2) venting is occurring primarily along abandoned mine tunnels and connecting fractures in the overlying rocks produced as tunnel roofs collapse.

Unlike the Tiptop mine fire, the Ruth Mullins mine fire is producing a variety of mineral sublimates on surfaces adjacent to the vent, be they rock or organic (Fig. 5). Most of the minerals are generally white and grow in dendritic, lacy forms. Many are yellowed by co-deposited tars. Minerals are most abundant surrounding the most active vents. In November, this was surrounding vents 3 and 5. By February, little activity was noted at vent 3 and the mineral deposits were largely weathered away. Active deposition was continuing at vent 5 .

Analysis of bulk mineral and soil samples collected in November 2009 indicates that the majority of minerals collected from vents 1, 3, and 5 are salammoniac (PDF file \#01-073-0365). Analysis of fairly homogeneous samples collected from vents 1 and 3 indicates that epsomite (PDF file \#01-072-0696), Mg-sulfate hexahydrite (PDF file \#721068), gypsum (PDF file\#33-0311), muscovite (PDF file\#01-0721503), salammoniac, and quartz (PDF file\#46-1045) are present. All but muscovite and quartz are known to be readily soluble in water, indicating that it is likely that these species could be mobilized into the regional ground water. Work by Silva et al., 2011a, 2011bdetails the mineral forms identified through optical and nanomineralogic techniques, and supports results obtained by powder XRD.

Tars coat a variety of surfaces at the Ruth Mullins coal mine fire (Fig. 5), including ice in the winter months. These tars contain potentially hazardous levels of both petroleum hydrocarbons and PAHs (Table 4). Among the documented health effects of these compounds are hemolytic anemia (Medlineplus, 2012) for naphthalene and cancer (International Agency for Research on Cancer, 2002) for naphthalene and other PAHs, such as benzo $[a]$ pyrene, benz $[a]$ anthracene, chrysene, benzo[b]fluoranthene, benzo[ $k]$ fluoranthene, dibenz $[a, h]$ anthracene, and indeno[1,2,3-cd]pyrene (US EPA, 2007). Obvious care should be taken to limit exposure to these tars.

Vent gas emissions contain aliphatic compounds with carbon numbers ranging from C1-C7 (Table 3), and abundant aromatic BTEX compounds, especially benzene and toluene. Concentrations of the organic compounds vary considerably between vents, such as 0.27 to $1174 \mathrm{ppm} \mathrm{CO}$ and 410 to $70,526 \mathrm{ppm} \mathrm{CO}_{2}$ in vents 4 and $3 \mathrm{~b}$, respectively, at the time of the January 2010 sampling. Overall, for the January 2010 analyses, those two vents generally represent the extremes in concentrations for these gases. The VOC concentrations measured in November 2009 are greater than those from the January 2010 dataset. An important caveat in the latter observation is that changes in vent configurations prevented us from sampling the same vents. Therefore, we cannot be certain if variations in emissions reflect, for example, (1) variations due to the selection of vents to be sampled, (2) changes in the position of the active fire front, (3) responses to atmospheric conditions, or (4) some combination of some or all of the variables.

\subsection{Examination of patterns in vent data}

Principal component analysis of the vent data (three principal components, $74.6 \%$ of variance explained) shows that the vent data from the two fires are easily distinguishable with high flow rates for the Tiptop fire, compared with higher concentrations of $\mathrm{CH}_{4}, \mathrm{CO}_{2}$, and $\mathrm{H}_{2} \mathrm{~S}$ and higher barometric pressures observed in data for the Ruth Mullins fire (Fig. 6). Inverse relationships between flow rate and gas concentration suggests that at higher gas transport rates, trace gases from the fire are lower. This effect may represent dilution by atmospheric gases when the pressure gradient (either internal or external to the fire) causes increased flow. A linear trend " A" in the upper panel of Fig. 6) for the Tiptop data in the PC biplots from higher temperature and $\mathrm{CO}$ concentrations with lower humidity and flow rates in vents $6,8,9$, and 10 to lower temperature and $\mathrm{CO}$ concentration with higher flow rates in vents 1,2 , and 7 suggests spatial controls on the fire. Of note, $\mathrm{CH}_{4}$ and $\mathrm{CO}_{2}$ concentrations appear strongly associated while $\mathrm{CO}$, an intermediate product between the two, appears unrelated. Such findings suggest that the system is not in a steady state and that CO may be rapidly converted to $\mathrm{CO}_{2}$, and that its lifetime in the fire is rather short. However, $\mathrm{CO}$ concentration appears closely linked with vent temperature. More so, volume ratios of $\mathrm{CO} / \mathrm{CH}_{4}$ decrease notably as a function of temperature (Fig. 7) suggesting more $\mathrm{CH}_{4}$ production and/or more rapid $\mathrm{CO}$ oxidation at higher temperatures. Such findings indicate that although the controls on the relative amounts of $\mathrm{CH}_{4}, \mathrm{CO}$, and $\mathrm{CO}_{2}$ in 

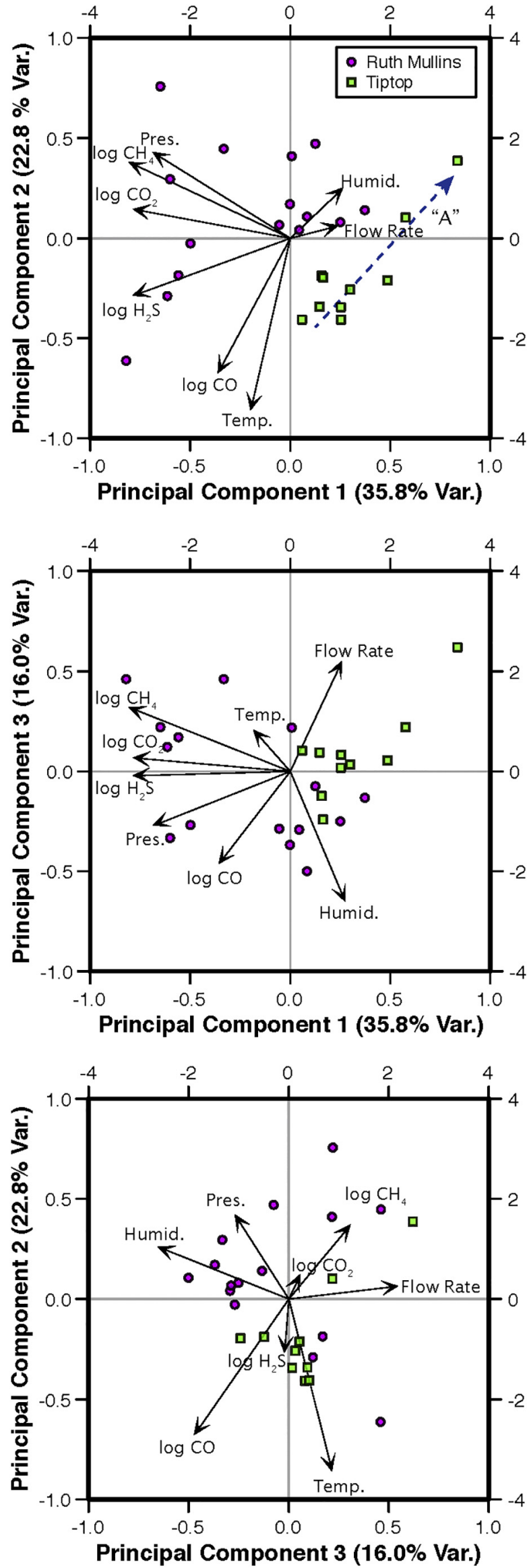

Fig. 6. Principal component biplot showing sample scores and parameters loadings for the first three components of the Ruth Mullins and Tiptop fires.

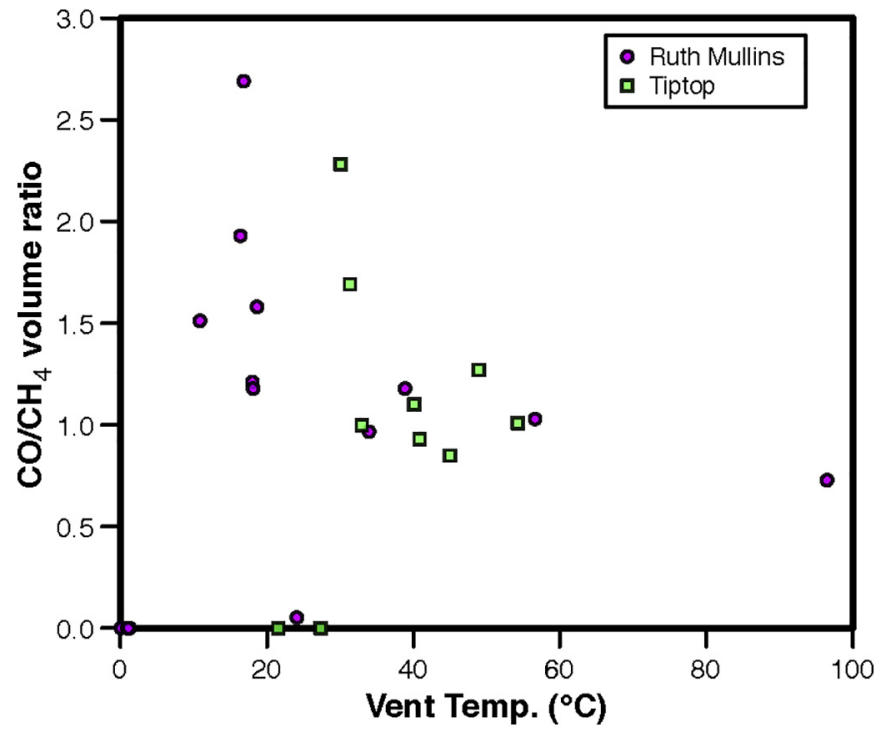

Fig. 7. Plot of the $\mathrm{CO} / \mathrm{CH}_{4}$ volume ratio in coal fire gas vent samples as a function of vent temperature at the Ruth Mullins and Tiptop fires.

coal fires are not well understood, the rate of $\mathrm{CO}$ production and loss appears to be a dynamic and important component. Given the large difference in greenhouse gas effect between $\mathrm{CH}_{4}$ and $\mathrm{CO}_{2}$, a better understanding of the factors controlling the relative ratio of the two gases in coal fire emissions is needed.

\section{Conclusions}

The Tiptop fire seemed to be nearing the end of its life at the time of our 2009 visit. At that time, the projected $\mathrm{CO}_{2}$ emissions from the fire were about $118 \mathrm{~T} / \mathrm{yr}$, about $90 \%$ of that coming from vents. Principal component analysis of vent chemistry and physical characteristics at this site indicate a spatial transition from high CO concentration and temperature and low velocity gas to higher humidity and velocity gas with lower $\mathrm{CO}$ concentration and temperature.

The Ruth Mullins coal mine fire is dynamic. The fire front migrated significantly from 2007 to 2008, and was burning unpredictably along the north side of a ridge through 2010. Emissions variations appear to be at least in part seasonally controlled, but are also controlled by daily "breathing cycles" (Hower et al., 2011). To accurately estimate atmospheric greenhouse and toxic gas contributions by this fire, monitoring vent emissions six times a year is suggested. The combination of diffuse flux measurements and snow-melt patterns, an admittedly seasonallylimited technique, can be used to identify areas of active combustion where other methods are unavailable or unfeasible. Based on these studies, estimates of $\mathrm{CO}_{2}$ emission from the Ruth Mullins coal mine fire range from 734 to $5400 \mathrm{~T} / \mathrm{yr}$. Both values likely represent underestimates, as they only take the winter months into account. The estimates of the emissions of other gases include $\pm 240 \mathrm{~T} / \mathrm{yr} \mathrm{CO}, \pm 150 \mathrm{~T} /$ yr $\mathrm{CH}_{4}, \pm 0.81 \mathrm{~T} / \mathrm{yr} \mathrm{H}_{2} \mathrm{~S}$, and a maximum of $2.7 \mathrm{~g} / \mathrm{yr} \mathrm{Hg}$. Emission estimates for most gases using the new sampling design developed in 2009 produced relatively similar results compared to data collected using the initial setup involving Dräger tubes. A notable exception are the emission estimates for $\mathrm{Hg}$. Emission estimates using the Zeeman atomic absorbance analyzer are 5 orders of magnitude lower than our previous estimates $(0.84 \mathrm{~T} \mathrm{Hg} / \mathrm{yr})$ using the Jerome Instrument, suggesting the latter may have greatly over-estimated $\mathrm{Hg}$ concentrations in the vents.

Multivariate examination of vent chemistry and physical parameter data using data for both fires provided further insight. Concentrations of $\mathrm{CH}_{4}$ and $\mathrm{CO}_{2}$ are strongly associated but $\mathrm{CO}$, an intermediate product between the two, appears poorly correlated with both. This result 
indicates that controls on the $\mathrm{CO}$ production and loss rate are dynamic and rapid but not well understood.

Minerals, volatile and aromatic hydrocarbons, and tars found around vents at the coal fire sites contain compounds of concern. Among the aromatic hydrocarbons, benzene and toluene are relatively abundant.

\section{Disclaimer}

The use of brand and trade names is for descriptive purpose and does not imply endorsement by the U.S. Government.

\section{Acknowledgements}

This work was supported by NASA Cooperative Agreement NNG05GH07H through a Kentucky Space Consortium grant to J. O'Keefe. We could not have completed this study without our team of collaborators, which included 10 students, five of whom were undergraduates. X-ray diffraction work was accomplished on equipment acquired by P. Schroeder from a grant through the National Science Foundation (EAR-IF 0929912). M. Engle, J. East, N. Geboy, and R. Olea were supported by the U.S. Geological Survey Energy Resources Program.

\section{References}

Barletta, B., Meindari, S., Simpson, I.J., Zou, S., Rowland, F.S., Blake, D.R., 2008. Ambient mixing ratios of nonmethane hydrocarbons (NMHCs) in two major urban centers of the Pearl River delta (PRD) region: Guangzhou and Dongguan. Atmos. Environ. 42, 4393-4408.

Chatterjee, R.S., 2006. Coal fire mapping from satellite thermal IR data - a case example in Jharia coalfield, Jharkhand, India. ISPRS J. Photogramm. Remote Sens. 60, 113-128.

Coleman, J.J., Swanson, A.L., Meinardi, S., Sive, B.C., Blake, D.R., Rowland, F.S., 2001. Description of the analysis of a wide range of volatile organic compounds in whole air samples collected during PEM-tropics A and B. Anal. Chem. 73, 3723-3731.

Dindarloo, S.R., Hood, M.M., Bagherieh, A., Hower, J.C., 2015. A statistical assessment of carbon monoxide emissions from the Truman Shepherd coal fire, Floyd County, Kentucky. Int. J. Coal Geol. 144-145, 88-97.

Emsbo-Mattingly, S.D., Stout, S.A., 2011. Semivolatile hydrocarbon residues of coal and coal tar chapter 11. In: Stracher, G.B. (Ed.), Coal and Peat Fires: A Global Perspective. Elsevier, Amsterdam.

Engle, M.A., 2018. Site Identification, Location, Temperature and $\mathrm{CO}_{2}$ Flux from Diffuse Emission Measurement at the Tiptop Coal Mine Fire. U.S. Geological Survey data release (2009), Kentucky. http://dx.doi.org/10.5066/F7PN94XJ.

Engle, M.A., Radke, L.F., Heffern, E.L., O'Keefe, J.M.K., Smeltzer, C.D., Hower, J.C., Hower, J.M., Prakash, A., Kolker, A., Eatwell, R.J., ter Schure, A., Queen, G., Aggen, K.L., Stracher, G.B., Henke, K.R., Olea, R.A., Román-Colón, Y., 2011. Quantifying $\mathrm{CO}_{2}$ emissions from coal fires using airborne and ground-based methods. Int. J. Coal Geol. 88, 147-151.

Engle, M.A., Radke, L.F., Heffern, E.L., O'Keefe, J.M.K., Hower, J.C., Smeltzer, C.D., Hower, J.M., Olea, R.A., Eatwell, R.J., Blake, D.R., Emsbo-Mattingly, S.D., Stout, S.A., Queen, G.R., Aggen, K.L., Kolker, A., Prakash, A., Henke, K.R., Stracher, G.B., Schroeder, P.A., Román-Colón, Y., ter Schure, A., 2012a. Gas emissions, minerals, and tars associated with three coal fires, Powder River basin, USA. Sci. Total Environ. 420, 146-159. http://dx.doi.org/10.1016/j.scitotenv.2012.01.037.

Engle, M.A., Olea, R.A., Hower, J.C., Stracher, G.B., Kolker, A., 2012b. In: Prakash, A., Sokol, E.V. Methods to Quantify Diffuse $\mathrm{CO}_{2}$ Emissions from Coal Fires Using Unevenly Distributed Flux Data: Coal and Peat Fires: a Global Perspective, vol. 2. Elsevier, Amsterdam (24 pp.) http://booksite.elsevier.com/9780444594129/ downloads/usgs/mark_engle.pdf.

Engle, M.A., Olea, R.A., O'Keefe, J.M.K., Hower, J.C., Geboy, N.J., 2013. Direct estimation of diffuse gaseous emissions from coal fires: current methods and future directions. Int. J. Coal Geol. 112, 164-172.

Garrison, T., O'Keefe, J.M.K., Henke, K.R., Copley, G.C., Blake, D.R., Hower, J.C., 2017 Gaseous emissions from the Lotts Creek coal mine fire: Perry County, Kentucky. Int. J. Coal Geol. 180, 57-66.

Gupta, R.P., Prakash, A., 1998. Reflection aureoles associated with thermal anomalies due to subsurface mine fires in the Jharia coalfield, India. Int. J. Remote Sens. 19, 2619-2622.

Hower, J.C., Henke, K., O'Keefe, J.M.K., Engle, M.A., Blake, D.R., Stracher, G.B., 2009. The Tiptop coal-mine fire, Kentucky: preliminary investigation of the measurement of mercury and other hazardous gases from coal-fire gas vents. Int. J. Coal Geol. 80,
63-67.

Hower, J.C., O'Keefe, J.M.K., Henke, K.R., Bagherieh, A.H., 2011. Time series analysis of CO emissions from an eastern Kentucky coal fire. Int. J. Coal Geol. 88, 227-231.

Hower, J.C., Copley, G.C., O'Keefe, J.M.K., Hower, J.M., 2012. The further adventures of Tin Man: vertical temperature gradients at the Lotts Creek coal mine fire, Perry County, Kentucky. Int. J. Coal Geol. 101, 16-20.

Hower, J.C., O'Keefe, J.M.K., Henke, K.R., Wagner, N.J., Copley, G., Blake, D.R., Garrison, T.M., Oliveira, M.L.S., Kautzmann, R.M., Silva, L.F.O., 2013. Gaseous emissions from the Truman Shepherd coal fire, Floyd County, Kentucky: a re-investigation following attempted mitigation of the fire. Int. J. Coal Geol. 116-117, 63-74.

Hron, K., Templ, M., Filzmoser, P., 2010. Imputation of missing values for compositional data using classical and robust methods. Comput. Stat. Data Anal. 54, 3095-3107.

Ide, S.T., Orr, F.M.J., 2011. Comparison of methods to estimate the rate of $\mathrm{CO}_{2}$ emissions and coal consumption from a coal fire near Durango, CO. Int. J. Coal Geol. 86 (1), 95-107.

International Agency for Research on Cancer, 2002. Some traditional herbal medicines, some mycotoxins, naphthalene and styrene. In: IARC Monographs on the Evaluation of Carcinogenic Risks to Humans. Vol. 82. http://monographs.iarc.fr/ENG/ Monographs/vol82/mono82.pdf, Accessed date: 30 March 2012

Jiang, L., Lin, H., Ma, J., Kong, B., Wang, Y., 2011. Potential of small-baseline SAR interferometry for monitoring land subsidence related to underground coal fires: Wuda (northern China) case study. Remote Sens. Environ. 115, 257.

Kolker, A., Engle, M.A., Hower, J.C., O'Keefe, J.M.K., Heffern, E.L., Radke, L.F., Stracher, G.B., Prakash, A., ter Schure, A., Olea, R., Román-Colón, Y., 2009a. Quantifying Atmospheric $\mathrm{CO}_{2}$ Emissions from Coal Fires: Sampling Approaches and Some U.S. Examples. Geological Society of America National Meeting Program with Abstracts. https://gsa.confex.com/gsa/2009AM/finalprogram/abstract 164466.htm.

Kolker, A., Engle, M.A., Hower, J.C., O'Keefe, J.M.K., Radke, L.F., Heffern, E.L., ter Schure, A., Stracher, G.B., Prakash, A., Román-Colón, Y., Olea, R., 2009b. Measuring $\mathrm{CO}_{2}$ emissions from coal fires in the U.S. proceedings. In: Annual International Pittsburgh Coal Conference, Pittsburgh, PA, September, 2009. Cd-Rom Publication.

Medlineplus, 2012. Naphthalene Poisoning. U.S. National Library of Medicine, National Institutes of Health. http://www.nlm.nih.gov/medlineplus/ency/article/002477. htm, Accessed date: 30 March 2012

Mishra, R.K., Bahuguna, P.P., Singh, V.K., 2011. Detection of coal mine fire in Jharia coal field using Landsat-7 ETM + data. Int. J. Coal Geol. 86, 73-78.

O'Keefe, J.M.K., Henke, K.R., Hower, J.C., Engle, M.A., Stracher, G.B., Stucker, J.D., Drew, J.W., Staggs, W.D., Murray, T.M., Hammond III, M.L., Adkins, K.D., Mullins, B.J., Lemley, E.W., 2010. $\mathrm{CO}_{2}$, CO, and Hg emissions from the Truman Shepherd and Ruth Mullins coal fires, eastern Kentucky, USA. Sci. Total Environ. 408, 1628-1633.

O'Keefe, J.M.K., Neace, E.R., Lemley, E.W., Hower, J.C., Henke, K.R., Copley, G., Hatch, R.S., Satterwhite, A.B., Blake, D.R., 2011. Old Smokey coal fire, Floyd County, Kentucky: estimates of gaseous emission rates. Int. J. Coal Geol. 87, 150-156.

Prakash, A., Berthelote, A.R., 2007. Subsurface coal mine fires: laboratory simulation, numerical modeling and depth estimation. Geol. Soc. Am. 18, 211-218.

Prakash, A., Vekerdy, Z., 2004. Design and implementation of a dedicated prototype GIS for coal fire investigations in North China: challenges met and lessons learnt. Int. J. Coal Geol. 59, 107-119.

Prakash, A., Singh, G., Singh, K.B., 2009. Appraisal of carbon monoxide emission at surface due to long standing underground fires in Jharia coalfield, India. J. Environ. Sci. Eng. 51, 107-110.

Prakash, A., Schaefer, K., Witte, W.K., Collins, K., Gens, R., Goyette, M., 2011. Remote sensing - GIS based investigation of a boreal Forest coal fire. Int. J. Coal Geol. 86, 79-86.

Silva, L.F.O., Oliveira, M.L.S., Neace, E.R., O'Keefe, J.M.K., Henke, K.R., Hower, J.C., 2011a. Nanominerals and ultrafine particles in sublimates from the Ruth Mullins coal fire, Perry County, eastern Kentucky, USA. Int. J. Coal Geol. 85, 237-245.

Silva, L.F.O., Oliveira, M.L.S., Philippi, V., Serra, C., Dai, S., Xue, W., Chen, W., O'Keefe, J.M.K., Romanek, C.S., Hopps, S.G., Hower, J.C., 2011b. Geochemistry of carbon nanotube assemblages in coal fire soot, Ruth Mullins fire, Perry County, Kentucky Int. J. Coal Geol. 94, 206-213.

Singh, A.K., Singh, R.V.K., Singh, M.P., Chandra, H., Shukla, N.K., 2007. Mine fire gas indices and their application to Indian underground coal mine fires. Int. J. Coal Geol. 69, 192-204.

Stout, S.A., Emsbo-Mattingly, S.D., 2008. Concentration and character of PAHs and other hydrocarbons in coals of varying rank - implications for environmental studies of soils and sediments containing pariculate coal. Org. Geochem. 39, 801-819.

Stracher, G.B., Hower, J.C., Schroeder, P.A., Fleisher, C., Kitson, J., Barwick, L.H., Hiett, J., Mardon, S.M., Carroll, R.E., Emsbo-Mattingly, S.D., 2008. Environmental dangers of coal fires in Kentucky and Alabama. Geological Society of America Abstracts with Program, paper 310-7. https://gsa.confex.com/gsa/2008AM/finalprogram/abstract 142640.htm.

Stracher, G.B., Prakash, A., Sokol, E., 2010. Coal and Peat Fires: A Global Perspective, Volume 1: Coal. Geology and Combustion. Elsevier, Inc., Amsterdam, pp. 380.

United States Environmental Protection Agency, 2007. Polycyclic Organic Matter (POM). http://www.epa.gov/ttn/atw/hlthef/polycycl.html, Accessed date: 30 March 2012.

Wu, J., Liu, X., 2011. Risk assessment of underground coal fire development at regional scale. Int. J. Coal Geol. 86, 87-94.

Zhang, J., Kuenzer, C., 2007. Thermal surface characteristics of coal fires 1: results of insitu measurements. J. Appl. Geophys. 63, 117-134. 